\title{
Study of the impact of a dynamic in vitro model of the colon (TIM-2) in the phenolic composition of two Mexican sauces
}

Citation for published version (APA):

Cárdenas-Castro, A. P., Venema, K., Sarriá, B., Bravo, L., Sáyago-Ayerdi, S. G., \& Mateos, R. (2021). Study of the impact of a dynamic in vitro model of the colon (TIM-2) in the phenolic composition of two Mexican sauces. Food Research International, 139, 109917. [109917]. https://doi.org/10.1016/j.foodres.2020.109917

Document status and date:

Published: 01/01/2021

DOI:

10.1016/j.foodres.2020.109917

Document Version:

Publisher's PDF, also known as Version of record

\section{Document license:}

Taverne

Please check the document version of this publication:

- A submitted manuscript is the version of the article upon submission and before peer-review. There can be important differences between the submitted version and the official published version of record.

People interested in the research are advised to contact the author for the final version of the publication, or visit the DOI to the publisher's website.

- The final author version and the galley proof are versions of the publication after peer review.

- The final published version features the final layout of the paper including the volume, issue and page numbers.

Link to publication

\footnotetext{
General rights rights.

- You may freely distribute the URL identifying the publication in the public portal. please follow below link for the End User Agreement:

www.umlib.nl/taverne-license

Take down policy

If you believe that this document breaches copyright please contact us at:

repository@maastrichtuniversity.nl

providing details and we will investigate your claim.
}

Copyright and moral rights for the publications made accessible in the public portal are retained by the authors and/or other copyright owners and it is a condition of accessing publications that users recognise and abide by the legal requirements associated with these

- Users may download and print one copy of any publication from the public portal for the purpose of private study or research.

- You may not further distribute the material or use it for any profit-making activity or commercial gain

If the publication is distributed under the terms of Article $25 \mathrm{fa}$ of the Dutch Copyright Act, indicated by the "Taverne" license above, 


\title{
Study of the impact of a dynamic in vitro model of the colon (TIM-2) in the phenolic composition of two Mexican sauces
}

\author{
Alicia Paulina Cárdenas-Castro ${ }^{\mathrm{a}}$, Koen Venema ${ }^{\mathrm{b}}$, Beatriz Sarriá ${ }^{\mathrm{c}}$, Laura Bravo ${ }^{\mathrm{c}}$, Sonia \\ G. Sáyago-Ayerdi ${ }^{a}$, Raquel Mateos ${ }^{c, "}$ \\ a Tecnológico Nacional de México/Instituto Tecnológico de Tepic, Av. Instituto Tecnológico No 2595, Col. Lagos del Country CP, 63175 Tepic, Nayarit, Mexico \\ ${ }^{\mathrm{b}}$ Maastricht University - Campus Venlo, Centre of Healthy Eating \& Food Innovation, St. Jansweg 20, 5928 RC Venlo, the Netherlands \\ ${ }^{\mathrm{c}}$ Institute of Food Science, Technology and Nutrition (ICTAN-CSIC). Spanish National Research Council (CSIC), José Antonio Nováis 10, 28040 Madrid, Spain
}

\section{A R T I C L E I N F O}

\section{Keywords:}

Mexican sauces

Husk tomato

Phenolic compounds

Indigestible fraction

Colonic fermentation

\begin{abstract}
A B S T R A C T
Husk tomato (Physalis ixocarpa Brot. ex. Horm) is mainly used in the preparation of many Mexican sauces due to its unique and slightly acidic flavor, both in raw and cooked forms. These sauces also usually contain Serrano hot pepper (Capsicum annum L), onion (Allium cepa L.), garlic (Allium sativum L.), coriander (Coriandrum sativum L.) and salt. Mexican sauces are a pre-Hispanic staple food, yet there is scarce knowledge on the phenolic compounds (PC) that reach the colon bound to the indigestible fraction (IF) after intestinal digestion. Thus, the aim of the present work was to evaluate the indigestible fraction of two types of Mexican sauces made with cooked and raw husk tomato: cooked green sauce (CGS) and raw green sauce (RGS). IF of CGS and RGS were fermented in the in vitro model of the human colon (TIM-2) to investigate the PC bioconversion by the gut microbiota after 24,48 and $72 \mathrm{~h}$. PC of the original sauces and their predigested fractions, as well as the formed metabolites were identified and monitored by HPLC-ESI-QToF-MS. Cooking husk tomato significantly increased the total indigestible fraction (TIF), mainly due to its insoluble indigestible fraction (IIF), and diminished PC. Flavonoids (flavonols and flavones) were the most abundant phenolic group in digested sauces followed by capsaicinoids (a characteristic group derived from hot pepper), hydroxycinnamic acids, and hydroxybenzoic acids. The metabolites 3-( $\rho$-hydroxyphenyl) propionic acid, 3-(3-hydroxyphenyl) propionic acid and 4-hydroxyphenylacetic acid were the most abundant colonic metabolites identified, which are thought to be derived from the biotransformation of flavonoids and hydroxycinnamates. These results are the first obtained on in vitro colonic fermentation of Mexican sauces and should be considered in future studies on the health effects related to consuming this staple food.
\end{abstract}

\section{Introduction}

Despite Mexico ranks second in world́s biodiversity of fruits and vegetables rich in bioactive compounds (BC) such as flavonoids and phenolic acids (Mercado-Mercado, Blancas-Benítez, Zamora-Gasga, \& Sáyago-Ayerdi, 2019), 86\% of their population presents nutritional and health problems (ENSANUT, 2016). Green Mexican sauces are one of the most representative and endemic foods which include the combination of husk tomato (Physalis ixocarpa Brot. ex. Horm.), hot pepper (Capsicum annuum L.), onion (Allium cepa L.), coriander (Coriandrum sativum L.), garlic (Allium sativum L.) and salt. Therefore, Mexican sauces are a mixture of vegetables with an individual significant content of phenolic compounds (PC) such as quercetin, caffeic and ferulic acid derivatives and capsaicinoids such as capsaicin (Cárdenas-Castro et al., 2019) which make this food healthy. According to this, PC are plant-derived metabolites considered bioactive BC with a substantial impact on human health due to their anti-inflammatory effects and prevention on the onset of diabetes, neurodegenerative or cardiovascular diseases (Williamson, Kay, \& Crozier, 2018). Notably, elucidating the PC exact daily intake or the complete content and profile of phenolic compounds in foods is still being challenging. Nevertheless, the release of the PC during the digestion process or their bioaccessibility becomes the key and limiting factor for the efficacy of their health-promising effects (Catalkaya et al., 2020). Indeed, cooking method, chemical structure of bioactive compounds or the interaction of the components of the indigestible fraction (IF) of foods, i.e., dietary fiber with PC or BC through

\footnotetext{
* Corresponding author.

E-mail address: raquel.mateos@ictan.csic.es (R. Mateos).
} 
non-covalent binding, van der Waals forces and hydrophobic interactions decrease their bioaccessibility in the small intestine (Jakobek \& Matić, 2019). Of note is that only PC bioaccessibility of Mexican sauces has been evaluated (Perales-Vázquez, Mercado-Mercado, de la Rosa, \& Sáyago-Ayerdi, 2020). Thus, knowledge on the PC that are not released in the small intestine and reach the colon associated to the indigestible fraction (IF) or predigested fraction is absent.

Hence, a percentage of $\mathrm{PC}$ and $\mathrm{BC}$ would reach the colon and nowadays it is clear the two-way interaction between BC and individuals' gut microbiota can determine the health effects of $\mathrm{BC}$ through their biotransformation by gut microbiota (Espín, González-Sarrías, \& Tomás-Barberán, 2017). In support of this notion, Wikan et al. (2020) concluded that capsaicinoid nonivamide, the metabolite produced by gut microbiota from capsaicin, has effects on nonalcoholic fatty liver disease by reducing glucose insulin resistance and fat deposition through the promotion of the insulin signaling pathway stimulating GLUT2 translocation to the membrane.

The validated TNO in vitro model of the colon (TIM-2) is a dynamic system that simulates the kinetic conditions of large intestine (Venema \& Van den Abbeele, 2013). This model allows screening the gut metabolites produced during the colonic fermentation to understand the biotransformation pathway of unabsorbed PC in the small intestine (Sáyago-Ayerdi, Zamora-Gasga, \& Venema, 2020).

Considering that the gut microbiota modulates the bioactivity of PC and capsaicinoids (Espín et al., 2017), that factors as cooking method may influence the bioaccessibility of BC (Perales-Vázquez et al., 2020) and that there are limited studies on Mexican sauces, the aim of the present study was to evaluate the fermentation of the indigestible fraction of two Mexican sauces made with cooked and raw husk tomato [cooked green sauce (CGS) and raw green sauce (RGS)], and the colonic biotransformation of the associated phenolic compounds and capsaicinoids. With this purpose, the in vitro model of the human colon (TIM-2) was used to investigate the PC bioconversion by the human gut microbiota.

\section{Materials and methods}

\subsection{Preparation of green sauces}

The two green Mexican sauces were prepared with defined proportions based on formulations by Perales-Vázquez et al. (2020), containing (per $100 \mathrm{~g}$ of sauce) $82.00 \mathrm{~g}$ of husk tomato (Physalis ixocarpa Brot. ex. Horm), $10.80 \mathrm{~g}$ white onion (Allium cepa L.), $3.34 \mathrm{~g}$ hot pepper (Capsicum annuum L.), $3.48 \mathrm{~g}$ coriander (Coriandrum sativum L.), $0.70 \mathrm{~g}$ garlic (Allium sativum L.), and $1.61 \mathrm{~g}$ of salt. The ingredients were purchased in a local supermarket in Tepic, Nayarit, Mexico. They were washed and disinfected with soap using a vegetable/water ratio of $1 / 3$ $(\mathrm{w} / \mathrm{v})$. Afterwards, a typical home-cooking recipe was followed to prepare the cooked green sauce (CGS) and raw green sauce (RGS). Husk tomato was placed in a pot using water at a ratio of $1 / 1.5(\mathrm{w} / \mathrm{v})$ and boiled $\left(100{ }^{\circ} \mathrm{C}, 8 \mathrm{~min}\right)$. Then, all ingredients were grinded together for $15 \mathrm{~s}$ using a blender (Osterizer 4655) draining the $90 \%$ of cooking water and without water addition at speed 3 according to Perales-Vázquez et al. (2020). The same process was followed to prepare RGS without cooking the husk tomato. In order to ensure the sample homogeneity, CGS and RGS were frozen $\left(-80^{\circ} \mathrm{C}\right)$, freeze-dried (FreeZone 6, Labconco, Kansas, City, MO), grounded (Nutribullet, NBR-0804B, USA), sieved $(0.5 \mu \mathrm{m})$ and stored in sealed bags at $-20^{\circ} \mathrm{C}$ until analysis.

\subsection{Isolation and quantification of indigestible fraction (IF)/predigested fraction of sauces}

In order to evaluate the IF content of CGS and RGS, the freeze-dried samples were submitted to the protocol by Saura-Calixto, García-Alonso, Goñi, and Bravo (2000). The description of this protocol is provided in Electronic Suplementary Material (ESM-I). Total indigestible fraction
(TIF) was quantified as the sum of both IIF and SIF, and results were expressed as $\mathrm{g} / 100 \mathrm{~g} \mathrm{dw}$.

Additionally, in order to obtain the combined TIF or predigested fraction for the in vitro fermentation assays, the freeze-dried sauces were predigested by the same method with modifications as proposed by Tabernero, Venema, Maathuis, and Saura-Calixto (2011). Thus, after in vitro digestion, the combined IIF and SIF were dialyzed for $48 \mathrm{~h}$ and the resulting TIF was collected, frozen $\left(-80^{\circ} \mathrm{C}\right)$, freeze-dried (FreeZone 6$)$, grounded (Nutribullet), sieved $(0.5 \mu \mathrm{m})$ and stored in sealed bags at $-20{ }^{\circ} \mathrm{C}$ until analysis.

\subsection{Standardized microbiota: Processing stool samples}

Stool samples were collected from 7 healthy individuals (4 female and 3 male, 23-50 years old). Volunteers declared not suffering from any gastrointestinal diseases and not having consumed of antibiotics at least three months prior donation. They collected a fresh fecal sample in plastic jar containing a gastight bag with anaerobic packs (Anaero$\mathrm{Gen}^{\mathrm{TM}}$, Oxoid, Cambridge, UK). To standardize the microbiota, a fecal pool was prepared (500 g) in an anaerobic cabinet (Sheldon Lab Bactron IV, Cornelius, OR, USA) according to Venema, Nuenen, SmeetsPeeters, Minekus, and Havenaar (2000). The mixture was prepared with a dialysate solution (content per litre: $2.5 \mathrm{~g} \mathrm{~K}_{2} \mathrm{HPO}_{4} \cdot 3 \mathrm{H}_{2} \mathrm{O}$, $4.5 \mathrm{~g} \mathrm{NaCl}$, $0.005 \mathrm{~g} \mathrm{FeSO}_{4} \cdot 7 \mathrm{H}_{2} \mathrm{O}, 0.5 \mathrm{~g} \mathrm{MgSO}_{4} \cdot \mathrm{H}_{2} \mathrm{O}, 0.45 \mathrm{~g} \mathrm{CaCl}_{2} \cdot 2 \mathrm{H}_{2} \mathrm{O}, 0.05 \mathrm{~g}$ oxbile, $0.4 \mathrm{~g}$ cysteine hydrochloride; $\mathrm{pH} 5.8)$ and glycerol (15\% w/w final concentration) as cryoprotective agent. Fecal suspension was aliquoted $(30 \mathrm{~mL})$, snap-frozen in liquid nitrogen and stored at $-80^{\circ} \mathrm{C}$.

\subsection{TIM-2: Experimental set up of the dynamic in vitro model of the human proximal large intestine}

TIM-2 is a validated, dynamic and computer-controlled in vitro model that mimics the human proximal large intestine using microbiota from human origin (Venema et al., 2000). This system simulates body temperature $\left(37^{\circ} \mathrm{C}\right)$, lumen $\mathrm{pH}(5.8)$, anaerobic conditions by flushing with gaseous $\mathrm{N}_{2}$, peristaltic movements and the absorption of water, as well as the removal of microbial metabolites, through a semipermeable membrane inside the model (Maathuis, Hoffman, Evans, Sanders, \& Venema, 2009). The fermentation was initiated with the injection of the pooled inoculum preparation into each of the 4 independent units of TIM-2 as follows: The fecal suspension, described above, was thawed during $1 \mathrm{~h}$ in a water bath at $37^{\circ} \mathrm{C}$. After this, the aliquot $(30 \mathrm{~mL})$ of fecal suspension was diluted with dialysate solution $(1: 1 \mathrm{v} / \mathrm{v})$ and transferred to a sterile plastic syringe. Then, TIM-2 was inoculated with $60 \mathrm{~mL}$ of the standardized microbiota which was adapted to model using the simulated ileal effluent medium (SIEM) for $16 \mathrm{~h}$ (described as "adaptation period", Fig. 1). The description of SIEM preparation is provided in Electronic Suplementary Material (ESM-I). The $\mathrm{pH}$ was adjusted to 5.8. After the "adaptation period", the feeding system was stopped for $2 \mathrm{~h}$, which is known as "starvation period" (Fig. 1). During this starvation period, the microbiota fermented the remaining carbohydrates from SIEM prior to the addition of predigested RGS and CGS. Sampling of the lumen and dialysate started when the starvation period ended (timepoint zero: $\mathrm{t}_{0}$ ). In one unit of the TIM-2, SIEM medium was fed as control whilst in two other units of the system, predigested RGS and CGS, mixed with SIEM without the indigestible carbohydrates, were fed $(7.5 \mathrm{~g} /$ day, $2.5 \mathrm{~mL} / \mathrm{h})$. Samples of the lumen and dialysate were collected at 24,48 and $72 \mathrm{~h}$ (Fig. 1).

\subsection{Extraction of phenolic compounds (PC) and capsaicinoids from sauces (CGS and RGS), predigested sauces and fermentation samples}

PC and capsaicinoids were extracted using the method developed by Bravo, Goya, and Lecumberri (2007). CGS, RGS or predigested samples $(0.5 \mathrm{~g})$ were extracted with $2 \mathrm{~N}$ hydrochloric acid in aqueous methanol $(50: 50 \mathrm{v} / \mathrm{v})$ and then with acetone:water $(70: 30 \mathrm{v} / \mathrm{v})$ for $1 \mathrm{~h}$ with 

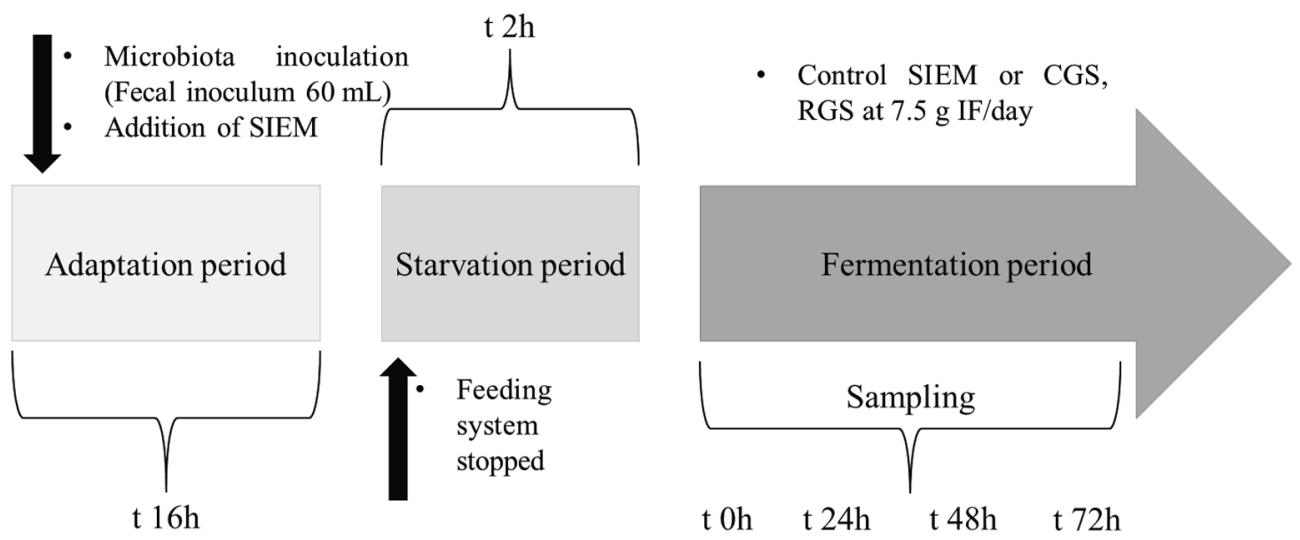

Fig. 1. Experimental setup of fermentation experiment in TIM-2. SIEM: Simulated Ileal Effluent Medium. CGS: Cooked green sauce; RGS: Raw green sauce. IF: Indigestible fraction.

constant shaking at room temperature. After each extraction step, samples were centrifuged (10 $\mathrm{min}, 3000 \mathrm{rpm})$ and the supernatants collected, combined and made up to $50 \mathrm{~mL}$. An aliquot of $2 \mathrm{~mL}$ was filtered through a $0.45 \mu \mathrm{M}$ pore-size cellulose-acetate membrane filter and dispensed into chromatographic vials. Regarding fermentation samples from TIM-2, an aliquot of $2 \mathrm{~mL}$ was placed in a microtube and centrifuged for $30 \mathrm{~min}$ at $12,300 \mathrm{rpm}\left(4^{\circ} \mathrm{C}\right)$, filtered as described above and dispensed in chromatographic vials. All the samples were stored at $-80{ }^{\circ} \mathrm{C}$ until analysis.

\subsection{Identification and quantification of phenolic compounds (PC) and capsaicinoids from sauces (CGS and RGS), predigested sauces and metabolites from fermentation samples by HPLC-ESI-QToF analysis}

The identification and quantification of PC and capsaicinoids by HPLC-ESI-QToF was determined following the procedure described by Gómez-Juaristi, Martínez-López, Sarria, Bravo, and Mateos (2018). Analysis were performed on an Agilent 1200 series LC system coupled to an Agilent 6530A Accurate-Mass Quadrupole Time-Of-Flight (Q-ToF) with ESI-Jet Stream Technology (Agilent Technologies). Compounds were separated on a reverse-phase Ascentis Express C18 $(15 \mathrm{~cm} \times 3 \mathrm{~mm}$, $2.7 \mu \mathrm{m}$ ) column (Sigma-Aldrich Química, Madrid) preceded by a Supelco 55215-U guard column at $30{ }^{\circ} \mathrm{C}$. The mobile phases used were Milli-Q water (A) and acetonitrile (B) both containing $0.1 \%$ formic acid (flow rate of $0.3 \mathrm{~mL} / \mathrm{min}, 5 \mu \mathrm{L}$ of sample injected). The mobile phase was initially $90 \% \mathrm{~A}$ and $10 \% \mathrm{~B}$. The elution program increased as follows: $30 \% \mathrm{~B}$ in $10 \mathrm{~min}, 40 \%$ of B in $5 \mathrm{~min}$ and $50 \%$ of B in $5 \mathrm{~min}$. Then, the initial conditions ( $10 \%$ solvent $\mathrm{B}$ ) were recovered in 2 min and maintained for $8 \mathrm{~min}$. The Q-ToF acquisition conditions were as follows: drying gas flow (nitrogen, purity $>99.9 \%$ ) and temperature were $10 \mathrm{~L} /$ min and $325^{\circ} \mathrm{C}$, respectively; sheath gas flow and temperature were $6 \mathrm{~L} /$ min and $250{ }^{\circ} \mathrm{C}$, respectively; nebulizer pressure was $25 \mathrm{psi}$; cap voltage was $3500 \mathrm{~V}$ and nozzle voltage was $500 \mathrm{~V}$. Mass range selected was from 100 up to $970 \mathrm{~m} / \mathrm{z}$ in negative mode and fragmentor voltage of $150 \mathrm{~V}$. Data were processed in a Mass Hunter Workstation Software. Compound identification was based on retention time and mass spectra obtained using HPLC coupled to ESI-QToF-MS along with analytical standard and/or information previously reported in the literature.

External calibration curves were prepared with the following standards purchased in Sigma-Aldrich: $\rho$-coumaric acid (C9008), homovanillic acid (H-1252), protocatechuic acid (P-5630), isovanillic acid (220108), $\rho$-hydroxybenzoic acid (H-5376), luteolin (L9283), transferulic acid (128708), 3-(4-hydroxy-3-methoxyphenyl)propionic acid (17803), 4-hydroxyphenylacetic acid (H50004), 3-hydroxybenzoic acid (H20008), rutin (R-5143), quercetin (Q0125), epicatechin (E1753), sinapic acid (D-7927), caffeic acid (C-0625), 3,4-dihydroxyphenylacetic acid (D-9128), 3-(3-hydroxyphenyl)propionic acid (91779), 3-
( $\rho$-hydroxyphenyl)-propionic acid (H6386), 3-(3,4-dihydroxyphenyl) propionic acid (102601) and capsaicin (M2028). When the standard was not available, the calibration curve corresponding to its phenolic precursor was used to tentatively quantify the compound.

\subsection{Statistical analysis}

All analyses were performed in triplicate $(\mathrm{n}=3)$; mean values and standard deviations from each determination were calculated. Data were processed by ANOVA/Fishers' least significant difference test for all samples ( $\mathrm{p}<0.05$ ). All analyzes were performed using STATISTICA software, version 10.0 (StatSoft. Inc. 1984-2007, Tulsa, OK, USA).

\section{Results and discussion}

\subsection{Quantification of indigestible fraction (IF) of sauces (CGS and RGS) and their predigested fraction}

The IF comprises protein, phenolic compounds, lipids and dietary fiber that resists digestion and absorption in the small intestine and would reach the colon as bacterial substrate (Tabernero et al., 2011). The IF contents of CGS and RGS are shown in Fig. 2. Significant differences $(p<0.05)$ were found for soluble and insoluble indigestible fraction (SIF and IIF, respectively) as well for total indigestible fraction (TIF) content between the sauces. Since the main ingredient of both

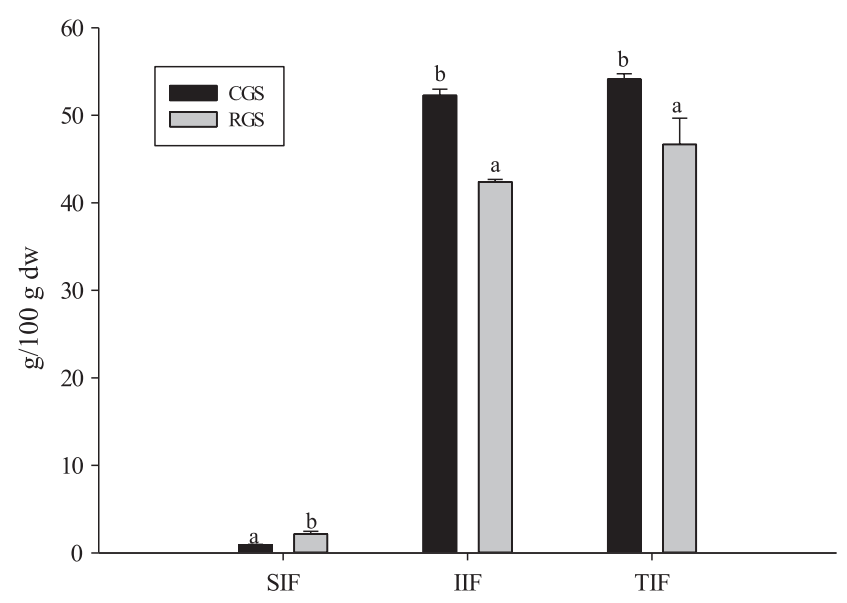

Fig. 2. Indigestible fraction content of $f \times 1$ cooked green sauce (CGS) and $f x 2$ raw green sauce (RGS). Values represent mean \pm SD $(n=3)$. Different letters indicate significant differences $(\mathrm{p}<0.05)$. dw: dry weight; TIF: Total Indigestible Fraction; SIF: Soluble Indigestible Fraction; IIF: Insoluble Indigestible Fraction. TIF $=$ SIF + IIF. 
sauces is husk tomato, which was submitted to thermal treatment in CGS, the differences in IF content could be explained by husk tomato thermal sensitivity. Although the SIF was a minor fraction compared to IIF, its content was significantly higher $(\mathrm{p}<0.05)$ in RGS $(2.16 \pm 0.30 \mathrm{~g} /$
$100 \mathrm{~g} \mathrm{dw})$ than in CGS $(0.92 \pm 0.04 \mathrm{~g} / 100 \mathrm{~g} \mathrm{dw})$, which could be explained by pectin thermal-solubilization during cooking. According to Morales-Contreras, Rosas-Flores, Contreras-Esquivel, Wicker, and

Morales-Castro (2018) husk tomato is a good source of pectin, with a

Table 1

HPLC-ESI-QToF-MS identification of phenolic compounds (PC) and capsaicinoids detected in cooked green sauce (CGS) and in raw green sauce (RGS).

\begin{tabular}{|c|c|c|c|c|c|c|c|c|c|c|c|}
\hline \multirow[t]{3}{*}{ Identified compound } & \multirow{3}{*}{$\begin{array}{l}\text { RT } \\
(\mathrm{min})\end{array}$} & \multirow{3}{*}{$\begin{array}{l}\text { Molecular } \\
\text { formula }\end{array}$} & \multirow{3}{*}{$\begin{array}{l}\text { Molecular } \\
\text { weight }\end{array}$} & \multirow[t]{3}{*}[\mathrm{M}-\mathrm{H}]{$^{-}$} & \multirow[t]{3}{*}{ MS $^{2}$ fragments } & \multicolumn{6}{|c|}{ Location } \\
\hline & & & & & & \multicolumn{2}{|c|}{ Sauce } & \multicolumn{2}{|c|}{ Digested } & \multicolumn{2}{|c|}{ Fermented } \\
\hline & & & & & & RGS & CGS & RGS & CGS & RGS & CGS \\
\hline \multicolumn{12}{|c|}{ HYDROXYCINNAMIC ACID AND RELATED COMPOUNDS } \\
\hline 1-Caffeoylquinic acid & 4.90 & $\mathrm{C}_{16} \mathrm{H}_{18} \mathrm{O}_{9}$ & 354.0951 & 353.0878 & 191 & nd & $\mathrm{x}$ & nd & $\mathrm{x}$ & nd & nd \\
\hline Caffeoyl hexose & 5.50 & $\mathrm{C}_{15} \mathrm{H}_{18} \mathrm{O}_{9}$ & 342.0951 & 341.0878 & $179 ; 135$ & nd & $\mathrm{x}$ & nd & nd & nd & nd \\
\hline Ferulic acid hexose & 6.20 & $\mathrm{C}_{16} \mathrm{H}_{20} \mathrm{O}_{9}$ & 356.1107 & 355.1035 & $193 ; 178$ & nd & nd & $\mathrm{x}$ & $\mathrm{x}$ & nd & nd \\
\hline Caffeoyl hexose & 7.20 & $\mathrm{C}_{15} \mathrm{H}_{18} \mathrm{O}_{9}$ & 342.0951 & 341.0878 & $179 ; 135$ & $\mathrm{x}$ & $\mathrm{x}$ & $\mathrm{x}$ & $\mathrm{x}$ & nd & nd \\
\hline Caffeoyl hexose & 7.60 & $\mathrm{C}_{15} \mathrm{H}_{18} \mathrm{O}_{9}$ & 342.0951 & 341.0878 & $179 ; 135$ & $\mathrm{x}$ & $\mathrm{x}$ & $\mathrm{x}$ & $\mathrm{x}$ & nd & nd \\
\hline 3-Caffeoylquinic acid & 7.70 & $\mathrm{C}_{16} \mathrm{H}_{18} \mathrm{O}_{9}$ & 354.0951 & 353.0878 & $191 ; 135$ & nd & $\mathrm{x}$ & nd & nd & nd & nd \\
\hline 5-Caffeoylquinic acid & 8.00 & $\mathrm{C}_{16} \mathrm{H}_{18} \mathrm{O}_{9}$ & 354.0951 & 353.0878 & $191 ; 179 ; 173 ; 135$ & nd & $\mathrm{x}$ & nd & $\mathrm{x}$ & nd & nd \\
\hline Coumaric acid hexose & 8.00 & $\mathrm{C}_{15} \mathrm{H}_{18} \mathrm{O}_{9}$ & 326.1002 & 325.0929 & 163 & $\mathrm{x}$ & nd & nd & nd & nd & nd \\
\hline Ferulic acid hexose & 9.00 & $\mathrm{C}_{16} \mathrm{H}_{20} \mathrm{O}_{9}$ & 356.1107 & 355.1035 & $193 ; 178$ & $\mathrm{x}$ & $\mathrm{x}$ & $\mathrm{x}$ & $\mathrm{x}$ & nd & nd \\
\hline Caffeic acid & 9.20 & $\mathrm{C}_{9} \mathrm{H}_{8} \mathrm{O}_{4}$ & 180.0423 & 179.0350 & 135 & nd & $\mathrm{x}$ & $\mathrm{x}$ & $\mathrm{x}$ & $\mathrm{x}$ & $\mathrm{x}$ \\
\hline Sinapic acid hexose & 9.20 & $\mathrm{C}_{17} \mathrm{H}_{22} \mathrm{O}_{10}$ & 386.1213 & 385.1140 & - & $\mathrm{x}$ & $\mathrm{x}$ & $\mathrm{x}$ & $\mathrm{x}$ & nd & nd \\
\hline 4-Caffeoylquinic acid & 9.40 & $\mathrm{C}_{16} \mathrm{H}_{18} \mathrm{O}_{9}$ & 354.0951 & 353.0878 & 191 & $\mathrm{x}$ & $\mathrm{x}$ & nd & $\mathrm{x}$ & nd & nd \\
\hline Coumaroylquinic acid & 9.80 & $\mathrm{C}_{16} \mathrm{H}_{18} \mathrm{O}_{8}$ & 338.1002 & 337.0929 & $191 ; 163$ & $\mathrm{x}$ & $\mathrm{x}$ & nd & nd & nd & nd \\
\hline Ferulic acid hexose & 10.00 & $\mathrm{C}_{16} \mathrm{H}_{20} \mathrm{O}_{9}$ & 356.1107 & 355.1035 & 193:178 & $\mathrm{x}$ & $\mathrm{x}$ & $\mathrm{x}$ & $\mathrm{x}$ & nd & nd \\
\hline Feruolylquinic acid & 10.70 & $\mathrm{C}_{17} \mathrm{H}_{20} \mathrm{O}_{9}$ & 368.1107 & 367.1035 & 191 & $\mathrm{x}$ & $\mathrm{x}$ & $\mathrm{x}$ & $\mathrm{x}$ & nd & nd \\
\hline Coumaroylquinic acid & 11.20 & $\mathrm{C}_{16} \mathrm{H}_{18} \mathrm{O}_{8}$ & 338.1002 & 337.0929 & 191 & $\mathrm{x}$ & $\mathrm{x}$ & nd & nd & nd & nd \\
\hline$\rho$-Coumaric acid & 11.75 & $\mathrm{C}_{9} \mathrm{H}_{8} \mathrm{O}_{3}$ & 164.0473 & 163.0401 & 119 & $\mathrm{x}$ & $\mathrm{x}$ & $\mathrm{x}$ & $\mathrm{x}$ & nd & $\mathrm{x}$ \\
\hline Feruolylquinic acid & 11.80 & $\mathrm{C}_{9} \mathrm{H}_{8} \mathrm{O}_{4}$ & 368.1107 & 367.1035 & 191 & $\mathrm{x}$ & $\mathrm{x}$ & $\mathrm{x}$ & $\mathrm{x}$ & nd & nd \\
\hline Sinapic acid & 12.85 & $\mathrm{C}_{11} \mathrm{H}_{12} \mathrm{O}_{5}$ & 224.0685 & 223.0612 & $208 ; 179 ; 149$ & $\mathrm{x}$ & $\mathrm{x}$ & $\mathrm{x}$ & $\mathrm{x}$ & nd & nd \\
\hline \multicolumn{12}{|c|}{ HYDROXYPHENYLPROPIONIC ACID AND RELATED COMPOUNDS } \\
\hline 3-(3,4-Dihydroxyphenyl) propionic acid & 8.55 & $\mathrm{C}_{9} \mathrm{H}_{10} \mathrm{O}_{4}$ & 182.0579 & 181.0506 & 137 & nd & nd & nd & nd & $\mathrm{x}$ & $\mathrm{x}$ \\
\hline 3-(p-Hydroxyphenyl) propionic acid & 11.20 & $\mathrm{C}_{9} \mathrm{H}_{10} \mathrm{O}_{3}$ & 166.063 & 165.0557 & 93 & nd & nd & nd & nd & $\mathrm{x}$ & $\mathrm{x}$ \\
\hline Methoxy-hydroxyphenylpropionic acid & 12.20 & $\mathrm{C}_{10} \mathrm{H}_{12} \mathrm{O}_{4}$ & 196.0736 & 195.0663 & 136 & nd & nd & nd & nd & $\mathrm{x}$ & $\mathrm{x}$ \\
\hline 3-(3-Hydroxyphenyl) propionic acid & 12.50 & $\mathrm{C}_{9} \mathrm{H}_{10} \mathrm{O}_{3}$ & 166.063 & 165.0557 & 93 & nd & nd & $\mathrm{x}$ & $\mathrm{x}$ & $\mathrm{x}$ & $\mathrm{x}$ \\
\hline HYDROXYPHENYLACETIC ACID AND & ATED CC & POUNDS & & & & & & & & & \\
\hline 3,4-Dihydroxyphenylacetic acid & 6.00 & $\mathrm{C}_{8} \mathrm{H}_{8} \mathrm{O}_{4}$ & 168.0423 & 167.0350 & $123 ; 108$ & nd & nd & nd & nd & $\mathrm{x}$ & $\mathrm{x}$ \\
\hline 3-Methoxy-4-hydroxyphenylacetic acid & 8.80 & $\mathrm{C}_{9} \mathrm{H}_{10} \mathrm{O}_{4}$ & 182.0579 & 181.0506 & 137 & nd & nd & nd & nd & $\mathrm{x}$ & $\mathrm{x}$ \\
\hline 4-Hydroxyphenylacetic acid & 8.90 & $\mathrm{C}_{8} \mathrm{H}_{8} \mathrm{O}_{3}$ & 152.0473 & 151.0401 & 107 & nd & nd & nd & nd & $\mathrm{x}$ & $\mathrm{x}$ \\
\hline HYDROXYBENZOIC ACID AND RELAT & COMPOL & & & & & & & & & & \\
\hline Hydroxybenzoic acid hexose & 4.40 & $\mathrm{C}_{13} \mathrm{H}_{16} \mathrm{O}_{8}$ & 300.0845 & 299.0772 & 137 (tentative) & $\mathrm{x}$ & $\mathrm{x}$ & $\mathrm{x}$ & $\mathrm{x}$ & nd & nd \\
\hline $\begin{array}{l}\text { 3,4-Dihydroxybenzoic acid } \\
\text { (protocatechuic acid) }\end{array}$ & 5.30 & $\mathrm{C}_{7} \mathrm{H}_{6} \mathrm{O}_{4}$ & 154.0266 & 153.0193 & 109 & nd & $\mathrm{x}$ & $\mathrm{x}$ & $\mathrm{x}$ & $\mathrm{x}$ & $\mathrm{x}$ \\
\hline Dihydroxybenzoic acid pentose & 6.00 & $\mathrm{C}_{12} \mathrm{H}_{14} \mathrm{O}_{8}$ & 286.0689 & 285.0616 & 153 & nd & $\mathrm{x}$ & nd & nd & nd & nd \\
\hline Hydroxybenzoic acid hexose & 6.90 & $\mathrm{C}_{13} \mathrm{H}_{16} \mathrm{O}_{8}$ & 300.0845 & 299.0772 & 137 (tentative) & $\mathrm{x}$ & $\mathrm{x}$ & $\mathrm{x}$ & $\mathrm{x}$ & nd & nd \\
\hline 4-Hydroxybenzoic acid & 8.04 & $\mathrm{C}_{7} \mathrm{H}_{6} \mathrm{O}_{3}$ & 138.0317 & 137.0244 & 93 (tentative) & nd & nd & nd & nd & $\mathrm{x}$ & $\mathrm{x}$ \\
\hline $\begin{array}{l}\text { 3-Hydroxy-4-methoxybenzoic acid } \\
\text { (Isovanillic acid) }\end{array}$ & 9.90 & $\mathrm{C}_{8} \mathrm{H}_{8} \mathrm{O}_{4}$ & 168.0423 & 167.0350 & $123 ; 91$ & nd & $\mathrm{x}$ & nd & nd & nd & nd \\
\hline p-Hydroxylbenzyaldheyde & 10.32 & $\mathrm{C}_{7} \mathrm{H}_{6} \mathrm{O}_{2}$ & 122.0368 & 121.0295 & - & $\mathrm{x}$ & $\mathrm{x}$ & $\mathrm{x}$ & $\mathrm{x}$ & $\mathrm{x}$ & $\mathrm{x}$ \\
\hline FLAVONOIDS & & & & & & & & & & & \\
\hline Rutin hexoside & 7.70 & $\mathrm{C}_{33} \mathrm{H}_{40} \mathrm{O}_{21}$ & 772.2062 & 771.1989 & 609 & $\mathrm{x}$ & $\mathrm{x}$ & $\mathrm{x}$ & $\mathrm{x}$ & nd & nd \\
\hline Apigenin acetyl hexoside & 10.30 & $\mathrm{C}_{21} \mathrm{H}_{30} \mathrm{O}_{12}$ & 474.1737 & 473.1664 & 431 & $\mathrm{x}$ & $\mathrm{x}$ & $\mathrm{x}$ & $\mathrm{x}$ & nd & nd \\
\hline Epicatechin gallate & 10.43 & $\mathrm{C}_{22} \mathrm{H}_{18} \mathrm{O}_{10}$ & 442.0900 & 441.0827 & 169 & $\mathrm{x}$ & nd & $\mathrm{x}$ & nd & nd & nd \\
\hline Myricetin-3-O-rutinoside & 10.46 & $\mathrm{C}_{27} \mathrm{H}_{30} \mathrm{O}_{17}$ & 626.1483 & 625.1410 & 317 & $\mathrm{x}$ & $\mathrm{x}$ & $\mathrm{x}$ & $\mathrm{x}$ & nd & nd \\
\hline Myricetin & 10.55 & $\mathrm{C}_{15} \mathrm{H}_{10} \mathrm{O}_{8}$ & 318.0376 & 317.0303 & 179 & $\mathrm{x}$ & $\mathrm{x}$ & $\mathrm{x}$ & $\mathrm{x}$ & nd & nd \\
\hline Rutin & 12.00 & $\mathrm{C}_{27} \mathrm{H}_{30} \mathrm{O}_{16}$ & 610.1534 & 609.1416 & 301 & $\mathrm{x}$ & $\mathrm{x}$ & $\mathrm{x}$ & $\mathrm{x}$ & nd & nd \\
\hline Quercetin-3-galactoside (Hyperin) & 12.30 & $\mathrm{C}_{21} \mathrm{H}_{20} \mathrm{O}_{12}$ & 464.0955 & 463.0882 & 301 & $\mathrm{x}$ & $\mathrm{x}$ & $\mathrm{x}$ & $\mathrm{x}$ & nd & nd \\
\hline Luteolin-7-O(2-apiosyl)glucoside & 12.35 & $\mathrm{C}_{26} \mathrm{H}_{28} \mathrm{O}_{15}$ & 580.1428 & 579.1355 & Tentative & $\mathrm{x}$ & $\mathrm{x}$ & $\mathrm{x}$ & $\mathrm{x}$ & nd & nd \\
\hline Quercetin-3-O-glucuronide & 12.44 & $\mathrm{C}_{27} \mathrm{H}_{18} \mathrm{O}_{13}$ & 478.0747 & 477.0675 & 301 & $\mathrm{x}$ & $\mathrm{x}$ & $\mathrm{x}$ & $\mathrm{x}$ & nd & nd \\
\hline Quercetin-3-glucoside (Isoquercitrin) & 12.50 & $\mathrm{C}_{21} \mathrm{H}_{20} \mathrm{O}_{12}$ & 464.0955 & 463.0882 & 301 & $\mathrm{x}$ & $\mathrm{x}$ & $\mathrm{x}$ & $\mathrm{x}$ & nd & nd \\
\hline Kaempferol-3-rutinoside & 13.10 & $\mathrm{C}_{27} \mathrm{H}_{30} \mathrm{O}_{15}$ & 594.1585 & 593.1512 & 285 & $\mathrm{x}$ & $\mathrm{x}$ & $\mathrm{x}$ & $\mathrm{x}$ & nd & nd \\
\hline $\begin{array}{l}\text { Luteolin 7-O-(2-apiofuranosyl-4- } \\
\text { glucopyranosyl-6-malonyl) }\end{array}$ & 13.30 & $\mathrm{C}_{35} \mathrm{H}_{40} \mathrm{O}_{23}$ & 828.1960 & 827.1888 & 783; 665 (tentative) & $\mathrm{x}$ & $\mathrm{x}$ & $\mathrm{x}$ & $\mathrm{x}$ & nd & nd \\
\hline $\begin{array}{l}\text { Quercetin-3-rhamnopiranoside } \\
\text { (Quercitrin) }\end{array}$ & 13.90 & $\mathrm{C}_{21} \mathrm{H}_{20} \mathrm{O}_{11}$ & 448.1006 & 447.0933 & $301 ; 151$ & $\mathrm{x}$ & $\mathrm{x}$ & $\mathrm{x}$ & $\mathrm{x}$ & $\mathrm{x}$ & nd \\
\hline Isorhamnetin-3-glucuronide & 14.20 & $\mathrm{C}_{22} \mathrm{H}_{20} \mathrm{O}_{13}$ & 492.0904 & 491.0831 & 151 & $\mathrm{x}$ & $\mathrm{x}$ & $\mathrm{x}$ & $\mathrm{x}$ & nd & nd \\
\hline Diosmetin-7-O- $\beta$-D-glucoside & 15.50 & $\mathrm{C}_{22} \mathrm{H}_{22} \mathrm{O}_{11}$ & 462.1162 & 461.0189 & $\begin{array}{l}301 ; 300 ; 60 \\
\text { (tentative) }\end{array}$ & $\mathrm{x}$ & $\mathrm{x}$ & $\mathrm{x}$ & $\mathrm{x}$ & nd & nd \\
\hline Luteolin & 17.70 & $\mathrm{C}_{15} \mathrm{H}_{10} \mathrm{O}_{6}$ & 286.0477 & 285.0405 & 199 & nd & nd & nd & nd & $\mathrm{x}$ & $\mathrm{x}$ \\
\hline Quercetin & 17.90 & $\mathrm{C}_{15} \mathrm{H}_{10} \mathrm{O}_{7}$ & 302.0427 & 301.0354 & 151 & $\mathrm{x}$ & $\mathrm{x}$ & $\mathrm{x}$ & $\mathrm{x}$ & $\mathrm{x}$ & $\mathrm{x}$ \\
\hline Kaempferol & 20.60 & $\mathrm{C}_{15} \mathrm{H}_{10} \mathrm{O}_{6}$ & 286.0477 & 285.0405 & $187 ; 89$ & nd & $\mathrm{x}$ & $\mathrm{x}$ & $\mathrm{x}$ & $\mathrm{x}$ & nd \\
\hline Isorhamnetin & 21.20 & $\mathrm{C}_{16} \mathrm{H}_{12} \mathrm{O}_{7}$ & 316.0583 & 315.051 & 300 & $\mathrm{x}$ & $\mathrm{x}$ & $\mathrm{x}$ & $\mathrm{x}$ & $\mathrm{x}$ & $\mathrm{x}$ \\
\hline CAPSAICINOIDS AND RELATED COMP & NDS & & & & & & & & & & \\
\hline Nonivamide & 25.40 & $\mathrm{C}_{17} \mathrm{H}_{27} \mathrm{NO}_{3}$ & 293.1991 & 292.1918 & 137 (tentative) & nd & nd & nd & nd & $\mathrm{x}$ & $\mathrm{x}$ \\
\hline Capsaicin & 26.00 & $\mathrm{C}_{18} \mathrm{H}_{27} \mathrm{NO}_{3}$ & 305.1991 & 304.1918 & 137 (tentative) & $\mathrm{x}$ & $\mathrm{x}$ & $\mathrm{x}$ & $\mathrm{x}$ & $\mathrm{x}$ & $\mathrm{x}$ \\
\hline
\end{tabular}


remarkable percentage of anhydrogalacturonic acid exceeding 60\%. Chigwedere et al. (2019) also reported a decrease of pectin content in cooked beans due to thermal treatment. In contrast, IIF content was significantly higher $(\mathrm{p}<0.05)$ in CGS $(52.26 \pm 0.72 \mathrm{~g} / 100 \mathrm{~g} \mathrm{dw})$ than in RGS $(42.39 \pm 0.27 \mathrm{~g} / 100 \mathrm{~g} \mathrm{dw})$. This corroborates our recent finding that thermal treatment increased the IIF content in fried beans due to the formation of carbohydrate/lipid complexes as well as structural changes that take place in the components of dietary fiber caused by heating (Cárdenas-Castro, Pérez-Jiménez, Bello-Pérez, Tovar, \& Sáyago-Ayerdi, 2020). Moreover, the peel of husk tomato is a source of sucrose esters and the thermal cooking process may increase the formation of insoluble indigestible components (Zhang, Khan, Bakht, \& Nair, 2016). Consequently, the TIF was significantly higher $(\mathrm{p}<0.05)$ in CGS $(54.11 \pm$ $0.63 \mathrm{~g} / 100 \mathrm{~g} \mathrm{dw})$ than in RGS $(46.65 \pm 3.00 \mathrm{~g} / 100 \mathrm{~g} \mathrm{dw})$.

\subsection{Identification and quantification of the phenolic compounds $(P C)$} and capsaicinoids of sauces (CGS and RGS) and predigested sauces

To the best of our knowledge, this is the first time that PC and capsaicinoids characterization (including quantification) in the original and predigested fraction in this type of green Mexican sauces is reported. The phenolic compounds released in the small intestine were reported by Perales-Vázquez et al. (2020). Moreover, although the phenolic composition of some ingredients of the sauces such as white onion, coriander or garlic is well known, and there is also information for other Physalis species (Medina-Medrano et al., 2015), there is no available data on the phenolic components in husk tomato (Physalis ixocarpa). It is also noteworthy that when sauces undergo simulated in vitro digestion, some PC could be released during digestion, and thus become bioaccessible for absorption and thus be able to pass into the bloodstream, whilst other PC associated to the IF of sauces would reach the colon and be available for the gut microbiota metabolization. In order to identify and quantify the PC and capsaicinoids in RGS and CGS before and after predigestion and fermentation, samples were analyzed by HPLC-ESIQToF-MS. Retention time (RT), molecular formula, molecular weight, accurate mass of the quasimolecular ion $[\mathrm{M}-\mathrm{H}]^{-}$after negative ionization, $\mathrm{MS}^{2}$ fragments and location (sauce, digested or fermentation samples) of the main compounds identified are listed in Table 1. Quantification of the PC and capsaicinoids identified in undigested and predigested CGS and RGS samples are shown in Table 2. Forty-five and thirty-eight compounds were quantified in undigested and predigested sauces, respectively. Total PC in CGS was significantly higher $(\mathrm{p}<0.05)$ than in RGS $(295 \pm 4 \mathrm{mg} / 100 \mathrm{~g}$ and $261 \pm 12 \mathrm{mg} / 100 \mathrm{~g} \mathrm{dw}$, respectively). This would suggest that thermal processing can enhance the release of IF-bound PC as Cárdenas-Castro et al. (2019) observed after studying cooked hot pepper, tomato and onion. Furthermore, PC of digested CGS and RGS significantly decreased to $41.0 \%$ and $49 \%$ of the initial amount, respectively. Thus, the content of PC in predigested samples was higher in CGS than in RGS $(173 \pm 2 \mathrm{mg} / 100 \mathrm{~g}$ and $132 \pm 4$ $\mathrm{mg} / 100 \mathrm{~g} \mathrm{dw}$, respectively). This decrease is due to the simulated passive diffusion through the cellulose membrane during dialysis. The significantly higher TIF and total PC content in CGS compared to RGS suggest that PC bound to the IF in the cooked sauces might be a good source of non-digested compounds that would be released in lower parts of the digestive tract (large intestine) (Jakobek \& Matić, 2019), and thus can potentially produce health benefits (Williamson et al., 2018).

As for capsaicinoids, contrary to what was described by Ornelas-Paz et al. (2010), capsaicin content was remarkably increased in the CGS in comparison with the raw sauce $(13.9 \mathrm{mg} / 100 \mathrm{~g}$ vs. $9 \mathrm{mg} / 100 \mathrm{~g}$ ), showing that boiling also increased the release of this compound (Table 2).

As mentioned above, the Mexican sauces evaluated in this manuscript were based mainly on husk tomato along with minor amounts of white onion, hot pepper, coriander and garlic. Certainly, all the ingredients contributed to the phenolic composition of both RGS and CGS. Therefore, PC of these sauces were numerous and heterogeneous, consisting of many PC belonging to different chemical groups such as hydroxycinnamic and hydroxybenzoic acids, and flavonoids as detailed in the following sections.

\subsubsection{Phenolic acids: hydroxycinnamic and hydroxybenzoic acids and related compounds}

Hydroxycinnamic acid and related compounds (Table 2) were a modest group of PC identified in these green sauces, amounting to 15.5 and $12.8 \%$ in RGS and CGS, respectively, of the total PC. No significant differences ( $p>0.05$ ) were observed among the hydroxycinnamic acids present in RGS in comparison with CGS. After digestion of both sauces, their content diminished significantly $(p<0.05)$ compared to their initial amount. Regarding the nature of identified compounds, glycosides of ferulic, sinapic, $\rho$-coumaric and caffeic acids, besides hydroxycinnamates such as caffeoylquinic, coumaroylquinic and feruloylquinic acids were the most abundant phenolic acids in both sauces. While glycosides of hydroxycinnamic acids (ferulic, caffeic, coumaric and sinapic acids) were significantly more abundant in RGS than in CGS, hydroxycinnamates showed the opposite tendency, with 89.7 and $52.6 \%$ of the total hydroxycinnamic acid derivatives in RGS and CGS, respectively (Table 2). It is important to mention that RGS did not present most of the isomers of caffeoylquinic acid (1-, 3-, 5- isomers), containing only 4-caffeoylquinic acid and significantly less than CGS ( $\mathrm{p}<0.05$ ). It seems that cooking the sauce could have favored the release of compounds covalently linked to polysaccharides in the plant cell wall in agreement with Bohn (2014), augmenting or even inducing the appearance of new PC, such as hydroxycinnamates which were almost absent in RGS (43.9\% and $7.3 \%$ in CGS and RGS, respectively). Therefore, free hydroxycinnamic acids such as coumaric, caffeic and sinapic acids were present in minor amounts (2.9 and 3.6\% of the total hydroxycinammic acids derivatives in undigested RGS and CGS, respectively) and no significant differences were observed between the sauces, except for caffeic acid, which was only present in undigested CGS. Previous, data has shown that caffeic acid is bound to dietary fiber (cellulose and xylan) by hydrogen bonds (Jakobek \& Matić, 2019), which could be easily released during cooking.

As shown in Table 2, in digested samples, a statistically significant decrease in glycosylated hydroxycinnamic acids was observed, although the amount of the corresponding aglycone did not compensate for the loss of these compounds. This may be explained by their simulated passive absorption through the cellulose membrane during the dialysis in the intestinal stage. Interestingly, no ferulic acid was identified in the digested samples in spite of the high amount of ferulic acid hexose in the original sauces (up to $21 \mathrm{mg} / 100 \mathrm{~g} \mathrm{dw}$ in RGS). Regarding hydroxycinnamates in the sauces, these compounds decreased or even disappeared completely after digestion except for 1-caffeoylquinic acid in CGS, which significantly increased.

Hydroxybenzoic acid derivatives were another group of PC identified in the Mexican sauces $(0.5$ and $1.2 \%$ of the total PC contained in RGS and CGS, respectively). Whereas glycosidic derivates of hydroxybenzoic acid were the compounds most abundant in RGS, the content significantly decreased $(\mathrm{p}<0.05)$ after cooking. It is noteworthy that dihydroxybenzoic acid pentose, protocatechuic acid and 3-hydroxy-4methoxybenzoic acid (isovanillic acid) were present in CGS and absent in RGS. In contrast, hydroxybenzaldehyde was identified in both RGS and CGS and a statistically significant decline of hydroxybenzoic acid derivatives was observed in the digested samples, with dihydroxybenzoic acid pentose and isovanillic acid even disappearing.

Regarding contents of hydroxycinnamic acids in white onion and garlic, Gorinstein et al. (2008) reported up to 0.28 and $0.054 \mathrm{mg} / 100 \mathrm{~g}$ $\mathrm{dw}$ of sinapic acid and 0.043 and $0.022 \mathrm{mg} / 100 \mathrm{~g}$ dw of $\rho$-coumaric acid in white onion and garlic, respectively. However, the content of these species of genus Allium in both green sauces were up to 4 times higher than those reported by Gorinstein et al. (2008). It is possible that the major ingredient in both sauces, husk tomato, could have contributed to the mentioned compounds. Up to date, no data about phenolic 
Table 2

Identified compounds in initial and digested (indigestible fraction) of raw green sauce (RGS) and cooked green sauce (CGS) (mg/100 g dw) ${ }^{1}$.

\begin{tabular}{|c|c|c|c|c|c|}
\hline \multirow[t]{2}{*}{ Compound } & \multirow[t]{2}{*}{ RT } & \multicolumn{2}{|l|}{ Initial Sauce } & \multicolumn{2}{|c|}{ Digested (Indigestible Fraction) } \\
\hline & & RGS & CGS & RGS & CGS \\
\hline \multicolumn{6}{|l|}{ HYDROXYCINNAMIC ACIDS AND RELATED COMPOUNDS } \\
\hline 1-Caffeoylquinic acid & 4.90 & N.D. & $0.49 \pm 0.04^{\mathrm{a}}$ & N.D. & $0.87 \pm 0.15^{\mathrm{b}}$ \\
\hline Caffeoyl hexose & 5.50 & N.D. & $0.18 \pm 0.06$ & N.D. & N.D. \\
\hline Ferulic acid hexose & 6.20 & N.D. & N.D. & $0.63 \pm 0.01^{\mathrm{a}}$ & $0.86 \pm 0.02^{\mathrm{b}}$ \\
\hline Caffeoyl hexose & 7.20 & $0.06 \pm 0.01^{\mathrm{ab}}$ & $0.03 \pm 0.01^{\mathrm{a}}$ & $0.11 \pm 0.01^{\mathrm{c}}$ & $0.09 \pm 0.01^{\mathrm{bc}}$ \\
\hline Caffeoyl hexose & 7.60 & $0.18 \pm 0.01^{\mathrm{b}}$ & $0.15 \pm 0.01^{b}$ & $0.10 \pm 0.01^{\mathrm{a}}$ & $0.09 \pm 0.01$ \\
\hline 3-Caffeoylquinic acid & 7.70 & N.D. & $7 \pm 1$ & N.D. & N.D. \\
\hline 5-Caffeoylquinic acid & 8.00 & N.D. & $0.48 \pm 0.02^{\mathrm{b}}$ & N.D. & $0.27 \pm 0.01^{\mathrm{a}}$ \\
\hline Coumaric acid hexose & 8.00 & $1.58 \pm 0.07$ & N.D. & N.D. & N.D. \\
\hline Ferulic acid hexose & 9.00 & $21 \pm 2^{c}$ & $9.24 \pm 0.04^{\mathrm{b}}$ & $0.88 \pm 0.03^{\mathrm{a}}$ & $0.78 \pm 0.01^{\mathrm{a}}$ \\
\hline Caffeic acid & 9.20 & N.D. & $0.10 \pm 0.01^{\mathrm{a}}$ & $0.10 \pm 0.01^{\mathrm{a}}$ & $1.38 \pm 0.04^{\mathrm{b}}$ \\
\hline Sinapic acid hexose & 9.20 & $11.9 \pm 0.7^{\mathrm{c}}$ & $8.1 \pm 0.1^{\mathrm{b}}$ & $2.30 \pm 0.02^{\mathrm{a}}$ & $2.10 \pm 0.01^{\mathrm{a}}$ \\
\hline 4-Caffeoylquinic acid & 9.40 & $0.32 \pm 0.01^{\mathrm{a}}$ & $3.7 \pm 0.3^{\mathrm{b}}$ & N.D. & $0.66 \pm 0.14$ \\
\hline Coumaroylquinic acid & 9.80 & $0.47 \pm 0.01^{\mathrm{b}}$ & $0.28 \pm 0.01^{\mathrm{a}}$ & N.D. & N.D. \\
\hline Ferulic acid hexose & 10.00 & $3.2 \pm 0.4^{\mathrm{c}}$ & $2.06 \pm 0.07^{\mathrm{b}}$ & $0.64 \pm 0.01^{\mathrm{a}}$ & $0.80 \pm 0.01^{\mathrm{a}}$ \\
\hline Feruloylquinic acid & 10.70 & $1.021 \pm 0.007^{\mathrm{b}}$ & $1.38 \pm 0.03^{\mathrm{c}}$ & $0.93 \pm 0.03^{\mathrm{a}}$ & $0.98 \pm 0.01^{\mathrm{ab}}$ \\
\hline Coumaroylquinic acid & 11.20 & $0.24 \pm 0.02^{\mathrm{a}}$ & $0.33 \pm 0.02^{\mathrm{b}}$ & N.D. & N.D. \\
\hline$\rho$-Coumaric acid & 11.75 & $0.16 \pm 0.01^{\mathrm{bc}}$ & $0.20 \pm 0.01^{\mathrm{c}}$ & $0.12 \pm 0.02^{\mathrm{ab}}$ & $0.09 \pm 0.01^{\mathrm{a}}$ \\
\hline Feruloylquinic acid & 11.80 & $1.01 \pm 0.07^{\mathrm{b}}$ & $3.73 \pm 0.00^{c}$ & $0.63 \pm 0.03^{\mathrm{a}}$ & $0.65 \pm 0.03^{\mathrm{a}}$ \\
\hline Sinapic acid & 12.85 & $1.07 \pm 0.01^{\mathrm{b}}$ & $1.09 \pm 0.01^{\mathrm{b}}$ & $1.01 \pm 0.01^{\mathrm{a}}$ & $1.01 \pm 0.01^{\mathrm{a}}$ \\
\hline \multirow[t]{2}{*}{ TOTAL (mg/ $100 \mathrm{~g} \mathrm{dw})$} & & $42 \pm 3^{b}$ & $39.5 \pm 1.3^{b}$ & $7.44 \pm 0.08^{a}$ & $10.9 \pm 0.4^{a}$ \\
\hline & & $(15.5 \%)$ & $(12.8 \%)$ & $(5.3 \%)$ & $(6.2 \%)$ \\
\hline \multicolumn{6}{|c|}{ HYDROXYPHENYLPROPIONIC ACIDS AND RELATED COMPOUNDS } \\
\hline 3-(3-Hydroxyphenyl) propionic acid & 12.50 & N.D. & N.D. & $0.22 \pm 0.01^{\mathrm{b}}$ & $0.09 \pm 0.01^{\mathrm{a}}$ \\
\hline \multirow[t]{2}{*}{ TOTAL $(\mathrm{mg} / 100 \mathrm{~g} \mathrm{dw})$} & & N.D. & N.D. & $0.22 \pm 0.01^{b}$ & $0.09 \pm 0.01^{a}$ \\
\hline & & $(0 \%)$ & $(0 \%)$ & $(0.2 \%)$ & $(0.1 \%)$ \\
\hline \multicolumn{6}{|l|}{ HYDROXYBENZOIC ACIDS AND RELATED COMPOUNDS } \\
\hline Hydroxybenzoic acid hexose & 4.40 & $0.58 \pm 0.03^{c}$ & $0.41 \pm 0.03^{\mathrm{b}}$ & $0.02 \pm 0.01^{\mathrm{a}}$ & $0.02 \pm 0.01^{\mathrm{a}}$ \\
\hline 3,4-Dihydroxybenzoic acid (protocatechuic acid) & 5.30 & N.D. & $0.48 \pm 0.03^{c}$ & $0.04 \pm 0.01^{\mathrm{a}}$ & $0.23 \pm 0.01^{\mathrm{b}}$ \\
\hline Dihydroxybenzoic acid pentose & 6.00 & N.D. & $0.11 \pm 0.01$ & N.D. & N.D. \\
\hline Hydroxybenzoic acid hexose & 6.90 & $0.61 \pm 0.06^{\mathrm{c}}$ & $0.34 \pm 0.01^{\mathrm{b}}$ & $0.04 \pm 0.01^{\mathrm{a}}$ & $0.03 \pm 0.01^{\mathrm{a}}$ \\
\hline 3-Hydroxy-4-methoxybenzoic acid (Isovanillic acid) & 9.90 & N.D. & $2.1 \pm 0.1$ & N.D. & N.D. \\
\hline p-Hydroxylbenzyaldheyde & 10.32 & $0.07 \pm 0.01^{\mathrm{b}}$ & $0.09 \pm 0.01^{\mathrm{b}}$ & $0.04 \pm 0.01^{\mathrm{a}}$ & $0.04 \pm 0.01^{\mathrm{a}}$ \\
\hline \multirow[t]{2}{*}{ TOTAL $(\mathrm{mg} / 100 \mathrm{~g} \mathrm{dw})$} & & $1.3 \pm 0.1^{c}$ & $3.63 \pm 0.09^{d}$ & $0.10 \pm 0.01^{a}$ & $0.31 \pm 0.01^{b}$ \\
\hline & & $(0.5 \%)$ & $(1.2 \%)$ & $(0.1 \%)$ & $(0.2 \%)$ \\
\hline \multicolumn{6}{|l|}{ FLAVONOIDS } \\
\hline Rutin hexoside & 7.70 & $0.10 \pm 0.01^{\mathrm{b}}$ & $0.07 \pm 0.01^{\mathrm{a}}$ & $0.06 \pm 0.01^{\mathrm{a}}$ & $0.06 \pm 0.01^{\mathrm{a}}$ \\
\hline Apigenin acetyl hexoside & 10.30 & $15.0 \pm 0.6^{\mathrm{c}}$ & $11 \pm 2^{\mathrm{b}}$ & $5 \pm 2^{\mathrm{a}}$ & $7 \pm 1^{\mathrm{ab}}$ \\
\hline Epicatechin gallate & 10.43 & $1.36 \pm 0.07^{\mathrm{b}}$ & N.D. & $0.09 \pm 0.01^{\mathrm{a}}$ & N.D. \\
\hline Myricetin-3-O-rutinoside & 10.46 & $4.1 \pm 0.1^{\mathrm{a}}$ & $10.9 \pm 0.5^{c}$ & $1.29 \pm 0.06^{\mathrm{b}}$ & $4.8 \pm 0.3^{\mathrm{a}}$ \\
\hline Myricetin & 10.55 & $0.7 \pm 0.2^{\mathrm{b}}$ & $2.30 \pm 0.06^{c}$ & $1.2 \pm 0.2^{\mathrm{a}}$ & $1.56 \pm 0.03^{\mathrm{a}}$ \\
\hline Rutin & 12.00 & $15 \pm 1^{\mathrm{c}}$ & $20.3 \pm 0.3^{\mathrm{d}}$ & $3.85 \pm 0.07^{\mathrm{a}}$ & $6.4 \pm 0.1^{\mathrm{b}}$ \\
\hline Quercetin-3-galactoside (Hyperin) & 12.30 & $3.4 \pm 0.3^{c}$ & $4.73 \pm 0.05^{\mathrm{d}}$ & $1.38 \pm 0.04^{\mathrm{a}}$ & $2.3 \pm 0.3^{\mathrm{b}}$ \\
\hline Luteolin-7-O(2-apiosyl)glucoside & 12.35 & $15.7 \pm 0.5^{\mathrm{a}}$ & $12 \pm 3^{\mathrm{a}}$ & $13 \pm 5^{\mathrm{a}}$ & $13.2 \pm 0.2^{\mathrm{a}}$ \\
\hline Quercetin-3-O-glucuronide & 12.44 & $93 \pm 5^{b}$ & $101 \pm 1^{\mathrm{c}}$ & $16.4 \pm 0.3^{\mathrm{a}}$ & $16.3 \pm 0.3^{\mathrm{a}}$ \\
\hline Quercetin-3-glucoside (Isoquercitrin) & 12.50 & $13.3 \pm 0.4^{\mathrm{a}}$ & $13.50 \pm 0.05^{\mathrm{a}}$ & $7.2 \pm 0.7^{\mathrm{b}}$ & $8.7 \pm 0.3^{c}$ \\
\hline Kaempferol-3-rutinoside & 13.10 & $4.8 \pm 0.3^{b}$ & $6.5 \pm 0.1^{\mathrm{c}}$ & $2.1 \pm 0.1^{\mathrm{a}}$ & $2.19 \pm 0.04^{\mathrm{a}}$ \\
\hline Luteolin 7-O-(2-apiofuranosyl-4-glucopyranosyl-6-malonyl) & 13.30 & $28 \pm 2^{\mathrm{a}}$ & $42.4 \pm 1.3^{\mathrm{c}}$ & $20.8 \pm 0.2^{\mathrm{b}}$ & $27 \pm 2^{\mathrm{a}}$ \\
\hline Quercetin-3-rhamnopiranoside (Quercitrin) & 13.90 & $11.7 \pm 0.4^{\mathrm{d}}$ & $5.6 \pm 0.1^{\mathrm{b}}$ & $6.9 \pm 0.5^{c}$ & $3.7 \pm 0.4^{\mathrm{a}}$ \\
\hline Isorhamnetin-3-glucoronide & 14.20 & $1.18 \pm 0.09^{\mathrm{b}}$ & $1.8 \pm 0.1^{\mathrm{c}}$ & $0.33 \pm 0.01^{\mathrm{a}}$ & $0.40 \pm 0.01^{\mathrm{a}}$ \\
\hline Diosmetin-7-O- $\beta$-D-glucoside & 15.50 & $7.3 \pm 0.1^{\mathrm{b}}$ & $4.6 \pm 0.2^{\mathrm{a}}$ & $3.7 \pm 0.2^{\mathrm{a}}$ & $4 \pm 1^{\mathrm{a}}$ \\
\hline Quercetin & 17.90 & $2.6 \pm 0.1^{\mathrm{a}}$ & $14.8 \pm 0.1^{\mathrm{b}}$ & $40 \pm 2^{c}$ & $63 \pm 1^{d}$ \\
\hline Kaempferol & 20.6 & N.D. & $0.21 \pm 0.08^{\mathrm{a}}$ & $0.18 \pm 0.02^{\mathrm{a}}$ & $0.92 \pm 0.04^{\mathrm{b}}$ \\
\hline Isorhamnetin & 21.2 & $0.12 \pm 0.01^{\mathrm{a}}$ & $0.08 \pm 0.01^{\mathrm{a}}$ & $0.20 \pm 0.03^{\mathrm{b}}$ & $0.24 \pm 0.04^{\mathrm{b}}$ \\
\hline \multirow[t]{2}{*}{ TOTAL $(\mathrm{mg} / 100 \mathrm{~g} \mathrm{dw})$} & & $218 \pm 9^{c}$ & $252 \pm 1^{d}$ & $124 \pm 5.7^{a}$ & $162 \pm 1^{b}$ \\
\hline & & $(80.6 \%)$ & $(81.6 \%)$ & $(88.3 \%)$ & $(92 \%)$ \\
\hline \multicolumn{6}{|l|}{ CAPSACINOIDS AND RELATED COMPOUNDS } \\
\hline Capsaicin & 26.0 & $9 \pm 1^{\mathrm{a}}$ & $13.9 \pm 1.7^{\mathrm{c}}$ & $9 \pm 1^{\mathrm{a}}$ & $2.7 \pm 0.6^{\mathrm{b}}$ \\
\hline \multirow[t]{2}{*}{ TOTAL (mg/ $100 \mathrm{~g} \mathrm{dw})$} & & $9 \pm 1^{a}$ & $13.9 \pm 1.7^{c}$ & $9 \pm 1^{a}$ & $2.7 \pm 0.6^{b}$ \\
\hline & & $(3.5 \%)$ & $(4.5 \%)$ & $(6.1 \%)$ & $(1.5 \%)$ \\
\hline TOTAL PC and CAPSAICINOIDS ( $\mathrm{mg} / 100 \mathrm{~g} \mathrm{dw})$ & & $270 \pm 12^{c}$ & $309 \pm 4^{d}$ & $141 \pm 4^{a}$ & $176 \pm 2^{b}$ \\
\hline
\end{tabular}

${ }^{1}$ Values represent mean \pm SD ( $=3$ ). Different lowercase letters in the same row indicate significant difference (p $<0.05$ ). N.D. $=$ not detected. Analytical pa-

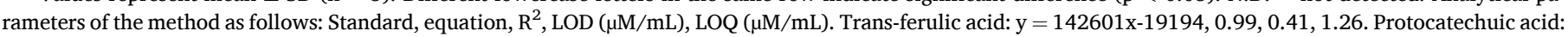

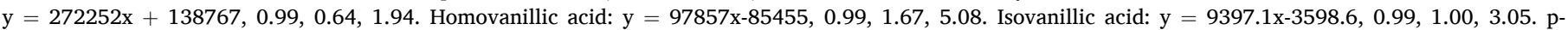

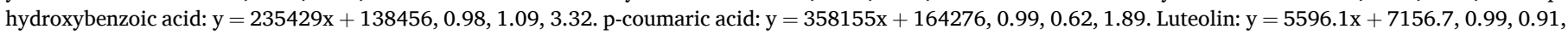

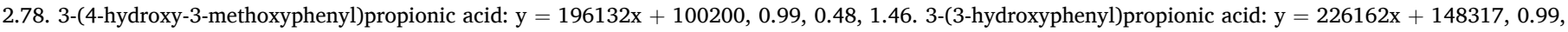

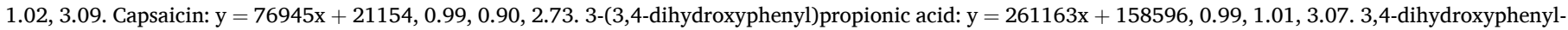

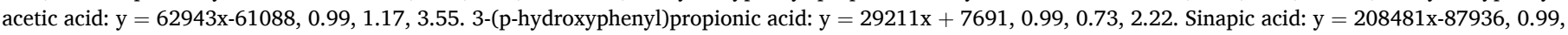

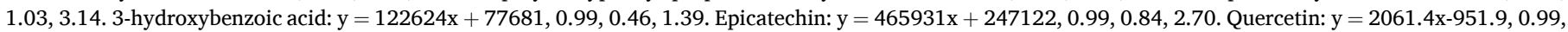

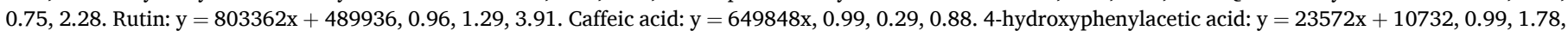
5.40. Linear range: LOQ-25 $(\mu \mathrm{M} / \mathrm{mL})$ 
characterization of husk tomato has been published, and thus no comparison may be made, since it differs from tomato fruit phenolic composition (Gómez-Romero, Segura-Carretero, \& Fernández-Gutiérrez, 2010).

\subsubsection{Flavonoids}

Flavonoids were the most abundant PC in green sauces, accounting for $80.6 \%$ and $81.6 \%$ of the total PC quantified in RGS and CGS, respectively, and $88.2 \%$ and $92.1 \%$ in predigested RGS and CGS, respectively. The contents of glycosidic derivatives of flavonols (quercetin, kaempferol, isorhamnetin, myricetin) and flavones (luteolin, diosmetin and apigenin) were significantly higher $(\mathrm{p}<0.05)$ than their aglycones in both initial sauces. Some glycosidic forms of flavonols and flavones diminished significantly after digestion of both sauces due to the presumably pass through dialysis membrane during simulated intestinal digestion (Table 2) except lutelolin-7-O-(2-apiosyl)glucoside which persisted after digestion. These results are in agreement with Juániz et al. (2016) who also observed no significant differences ( $p>$ 0.05 ) in the content of luteolin-7-O-(2-apiosyl)glucoside after the digestion of sweet Italian green pepper (Capsicum annuum L.).

The most abundant compound quantified in initial sauces was quercetin-3-O-glucuronide, the content of which significantly diminished after digestion. Coriander is an ingredient widely used in green sauces, which is particularly rich in quercetin-3-O-glucuronide (124 \pm 2 $\mathrm{mg} / 100 \mathrm{~g} \mathrm{dw}$; Barros et al., 2012). The amount of this flavonol in CGS and RGS accounted up to $101 \pm 1$ and $93 \pm 5 \mathrm{mg} / 100 \mathrm{~g} \mathrm{dw}$, respectively. However, coriander is a minor ingredient in the sauces, about $3.48 \%$ of the total sauce, so that the rest of vegetables would also contribute to the total amount of quercetin-3-O-glucuronide determined in these sauces. Apart from rutin hexoside, free rutin was also identified in both original and predigested sauces with a similar behavior to the rest of glycosylated derivatives. CGS showed a significantly higher amount of flavonol aglycones than RGS, increasing even more after digestion in both sauces (1.6 and $6.9 \%$ of the total flavonoids present in RGS and CGS, respectively, versus, 33.8 and $40.7 \%$ of the total flavonoids present in digested RGS and CGS, respectively), primarily due to large increases in quercetin.

Hot pepper, garlic and white onion are rich sources of quercetin, content in onion being $49 \pm 3 \mathrm{mg} / 100 \mathrm{~g} \mathrm{dw}$ as reported by Gorinstein et al. (2008). This amount was in line with the $2.6 \pm 0.2 \mathrm{mg} / 100 \mathrm{~g} \mathrm{dw}$ of quercetin quantified in RGS, taking into account that white onion represented $10.8 \%$ of the total sauce. Regarding myricetin, garlic is an important source of this flavonol $(69.30 \pm 0.01 \mathrm{mg} / 100 \mathrm{~g} \mathrm{dw}$; Miean \& Mohamed, 2001). Considering that garlic is the less abundant ingredient in green sauces ( $0.70 \%$ added), the amount quantified in RGS and CGS that ranged from 0.7 up to $2.30 \mathrm{mg} / 100 \mathrm{~g} \mathrm{dw}$ is coherent with Miean and Mohamed (2001).

Finally, epicatechin gallate was only identified in initial and predigested RGS samples, although its concentration was relatively low $(0.62 \%)$ compared to the total amount of flavonoids in RGS.

\subsubsection{Capsaicinoids}

The characteristic pungency in hot pepper is caused by capsaicin; in fact, it is the most abundant capsaicinoid found only in the Capsicum species. Alvarez-Parrilla, de la Rosa, Amarowicz, and Shahidi (2011) reported $161 \pm 6 \mathrm{mg} / 100 \mathrm{~g} \mathrm{dw}$ of capsaicin in Serrano hot pepper, which was the variety used to make the sauces of this study. The content of capsaicin in RGS and CGS ranged from 9 to $14 \mathrm{mg} / 100 \mathrm{~g} \mathrm{dw}$, respectively, which is equivalent to 5.6 and $8.7 \%$ of the amount reported by Alvarez-Parrilla et al. (2011). The present results are consistent with their work taking into account that the amount of pepper added to the sauces barely represents $3.4 \%$ of the total composition of the green sauces.

While no significant differences were found in the content of capsaicin between initial and predigested RGS, the content of this compound in predigested CGS significantly diminished $(\mathrm{p}<0.05)$ in comparison with initial, non-predigested CGS. Food matrix interactions with different compounds during digestion influence their bioaccessibility as described by Bohn (2014). It is suggested that capsaicin in CGS did not interact as much as in RGS food matrix, being more bioaccessible in CGS. Recently it was suggested that capsaicin acts an antiepileptic drug (Pasierski \& Szulczyk, 2020), evidencing its effect on central nervous.

The potential health effects related to the consumption of PC are believed to be due to both the phenolic fraction absorbed in the small intestine as well as to the metabolites formed by gut microbiota which are later absorbed (Serra et al., 2012). In the following section in vitro colonic fermentation of predigested RGS and CGS is presented and discussed.

\subsection{Phenolic compounds (PC) and capsaicinoids metabolites produced during in vitro colonic fermentation of IF isolated from CGS and RGS}

The PC profile of the TIF can influence colonic metabolites production as well as the microbiota composition during the fermentation process (Williamson et al., 2018). Some of the biotransformation reactions that PC can undergo catalyzed by the gut microbiota are deglycosylation, ester hydrolysis, C-ring cleavage, demethylation, methylation, dehydroxylation, hydroxylation, decarboxylation or double bound reduction (hydrogenation) (Espín et al., 2017). The metabolites produced during the in vitro colonic fermentation of predigested sauces in TIM-2 are shown in Table 3. It is remarkable that a few colonic metabolites identified in the fermentation samples were present in baseline samples $(t=0 \mathrm{~h})$. These metabolites corresponded to the fecal inoculum that was provided with the standard SIEM medium during the adaptation period according with previous results by Quatrin et al. (2020) who reported these metabolites in $t_{0}$ fermentation samples during the in vitro colonic fermentation of jaboticaba (Myrciaria trunciflora). In the present study, no significant differences were observed in the total amount of metabolites found at $t_{0}$ in fermented RGS and CGS (12.3 \pm 0.2 and $17 \pm 3 \mu \mathrm{M}$, respectively). Hydroxycinnamates and flavonoids were the main PC substrate for the gut microbiota (Table 2), while derivatives of hydroxyphenylpropionic and hydroxyphenylacetic acids constituted the major group of the colonic metabolites formed after the fermentation of both digested RGS and CGS. Regarding hydroxycinnamic acids, only caffeic and coumaric acids were detected in the fermented samples. After $72 \mathrm{~h}$ of fermentation, very low amounts of the acids were observed in CGS and none in RGS, while no hydroxycinnamates were detected. The importance of the colonic microbiota in the metabolism of hydroxycinnamic acids and its derivatives is well known (Gómez-Juaristi et al., 2018). Both hydroxycinnamates and glycosylated forms of hydroxycinnamic acids were hydrolyzed to form free hydroxycinnamic acids, which were subsequently reduced to dihydroxycinnamic acids or hydroxyphenylpropionic acids derivatives (Fig. 3) (Espín et al., 2017; Williamson \& Clifford, 2017; Williamson et al., 2018). Afterwards, hydroxyphenylpropionic acid derivatives might evolve to hydrophenylacetic acids and these, in turn, to dihydroxybenzoic acids by successive decarboxylation. Furthermore, monohydroxylic derivatives of phenylpropionic, phenylacetic and benzoic acids, in turn, may progress to dihydroxybenzoic acids by successive decarboxylation. Also, monohydroxylic derivatives of phenylpropionic, phenylacetic and benzoic acids were also identified by dehydroxylation of their respective precursor compound (Fig. 3). Analysis of colonic metabolites quantified in the fermentation samples revealed that the preferential pathway followed by 3-(3,4-dihydroxyphenyl) propionic and 3,4-dihydroxyphenylacetic acids was the dehydroxylation reaction according to the increasing amount observed for both or one of the monohydroxylated derivatives. Thus, 3-( $\rho$-hydroxyphenyl) propionic acid and 3-(3hydroxyphenyl) propionic acid evolved from 3.3 and $19.7 \mu$ moles at 24 $\mathrm{h}$ to 51 and $34.6 \mu$ moles at $72 \mathrm{~h}$, respectively, in RGS; and from 22 and $15.6 \mu$ moles at $24 \mathrm{~h}$ to 30 and $32 \mu$ moles at $72 \mathrm{~h}$, respectively, in CGS. Regarding monohydroxylated derivatives of phenylacetic acid, only 4 - 
Table 3

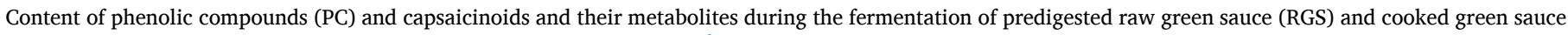
(CGS) using a dynamic in vitro model of the human colon from 0 to $72 \mathrm{~h}{ }^{1}$

\begin{tabular}{|c|c|c|c|c|c|c|c|c|c|}
\hline \multirow[b]{2}{*}{ Compound } & \multirow[b]{2}{*}{$\begin{array}{l}\text { RT } \\
(\mathrm{min})\end{array}$} & \multicolumn{2}{|c|}{0 ( $\mu$ moles) } & \multicolumn{2}{|c|}{$24 \mathrm{~h}$ ( $\mu$ moles) } & \multicolumn{2}{|c|}{$48 \mathrm{~h}$ ( $\mu$ moles) } & \multicolumn{2}{|c|}{$72 \mathrm{~h}$ ( $\mu$ moles) } \\
\hline & & RGS & CGS & RGS & CGS & RGS & CGS & RGS & CGS \\
\hline \multicolumn{10}{|c|}{ HYDROXYCINNAMIC ACIDS AND RELATED COMPOUNDS } \\
\hline Caffeic acid & 9.20 & N.D. & N.D. & Traces & $\begin{array}{l}0.05 \pm \\
0.01^{\mathrm{a}}\end{array}$ & Traces & $\begin{array}{l}0.11 \pm \\
0.01^{b}\end{array}$ & Traces & $\begin{array}{l}0.18 \pm \\
0.01^{\mathrm{c}}\end{array}$ \\
\hline$\rho$-Coumaric acid & 11.75 & N.D. & Traces & N.D & Traces & N.D & $\begin{array}{l}0.05 \pm \\
0.01^{\mathrm{a}}\end{array}$ & N.D & $\begin{array}{l}0.05 \pm \\
0.01^{\mathrm{a}}\end{array}$ \\
\hline \multicolumn{10}{|c|}{ HYDROXYPHENYLPROPIONIC ACIDS AND RELATED COMPOUNDS } \\
\hline 3-(3,4-Dihydroxyphenyl) propionic acid & 8.55 & N.D. & $\begin{array}{l}0.12 \pm \\
0.01^{\mathrm{a}}\end{array}$ & $\begin{array}{l}0.14 \pm \\
0.01^{\mathrm{a}}\end{array}$ & $\begin{array}{l}0.31 \pm \\
0.01^{\mathrm{c}}\end{array}$ & $\begin{array}{l}0.88 \pm \\
0.02^{\mathrm{b}}\end{array}$ & $\begin{array}{l}0.58 \pm \\
0.04^{\mathrm{d}}\end{array}$ & $\begin{array}{l}1.19 \pm \\
0.02^{\mathrm{e}}\end{array}$ & $\begin{array}{l}0.90 \pm \\
0.08^{\mathrm{b}}\end{array}$ \\
\hline 3-(p-Hydroxyphenyl) propionic acid & 11.20 & N.D & $8.8 \pm 0.4^{\mathrm{b}}$ & $3.3 \pm 0.3^{\mathrm{a}}$ & $22 \pm 1^{\mathrm{c}}$ & $33 \pm 2^{\mathrm{f}}$ & $25.0 \pm 0.8^{\mathrm{d}}$ & $51 \pm 2^{g}$ & $30 \pm 1^{\mathrm{e}}$ \\
\hline Methoxy-hydroxyphenylpropionic acid & 12.20 & N.D. & $\begin{array}{l}0.06 \pm \\
0.01^{\mathrm{a}}\end{array}$ & $\begin{array}{l}0.16 \pm \\
0.01^{\mathrm{b}}\end{array}$ & $\begin{array}{l}0.04 \pm \\
0.01^{\mathrm{a}}\end{array}$ & $\begin{array}{l}0.47 \pm \\
0.02^{\mathrm{d}}\end{array}$ & $\begin{array}{l}0.13 \pm \\
0.02^{\mathrm{b}}\end{array}$ & $\begin{array}{l}0.67 \pm \\
0.01^{\mathrm{e}}\end{array}$ & $\begin{array}{l}0.25 \pm \\
0.02^{\mathrm{c}}\end{array}$ \\
\hline 3-(3-Hydroxyphenyl) propionic acid & 12.50 & N.D. & $6.3 \pm 0.3^{\mathrm{a}}$ & $19.7 \pm 0.5^{\mathrm{c}}$ & $15.6 \pm 0.9^{\mathrm{b}}$ & $29.6 \pm 0.2^{\mathrm{e}}$ & $23.4 \pm 0.4^{\mathrm{d}}$ & $34.6 \pm 0.6^{g}$ & $32 \pm 1^{\mathrm{f}}$ \\
\hline \multicolumn{10}{|c|}{ HYDROXYPHENYLACETIC ACIDS AND RELATED COMPOUNDS } \\
\hline 3,4-Dihydroxyphenylacetic acid & 6.00 & N.D. & N.D. & $\begin{array}{l}0.52 \pm \\
0.07^{\mathrm{b}}\end{array}$ & $\begin{array}{l}0.18 \pm \\
0.01^{\mathrm{a}}\end{array}$ & $\begin{array}{l}1.26 \pm \\
0.02^{\mathrm{c}}\end{array}$ & $\begin{array}{l}0.25 \pm \\
0.02^{\mathrm{a}}\end{array}$ & $\begin{array}{l}1.93 \pm \\
0.04^{\mathrm{d}}\end{array}$ & $\begin{array}{l}0.25 \pm \\
0.01^{\mathrm{a}}\end{array}$ \\
\hline 3-Mehoxy-4-hydroxyphenylacetic acid & 8.80 & N.D. & $\begin{array}{l}0.31 \pm \\
0.01^{\mathrm{a}}\end{array}$ & $\begin{array}{l}0.39 \pm \\
0.03^{\mathrm{a}}\end{array}$ & $\begin{array}{l}0.84 \pm \\
0.02^{\mathrm{c}}\end{array}$ & $\begin{array}{l}2.31 \pm \\
0.04^{\mathrm{b}}\end{array}$ & $1.6 \pm 0.1^{\mathrm{d}}$ & $\begin{array}{l}3.12 \pm \\
0.03^{\mathrm{e}}\end{array}$ & $2.4 \pm 0.2^{\mathrm{b}}$ \\
\hline 4-Hydroxyphenylacetic acid & 8.90 & $\begin{array}{l}12.3 \pm \\
0.2^{\mathrm{d}}\end{array}$ & $1.1 \pm 0.9^{c}$ & $33 \pm 6^{a}$ & $32.1 \pm 0.7^{\mathrm{a}}$ & $62 \pm 4^{b}$ & $47 \pm 3^{e}$ & $94 \pm 2^{f}$ & $62 \pm 4^{b}$ \\
\hline \multicolumn{10}{|c|}{ HYDROXYBENZOIC ACIDS AND RELATED COMPOUNDS } \\
\hline $\begin{array}{l}\text { 3,4-Dihydroxybenzoic acid (Protocatechuic } \\
\text { acid) }\end{array}$ & 5.30 & N.D. & N.D. & $\begin{array}{l}0.28 \pm \\
0.04^{\mathrm{b}}\end{array}$ & $\begin{array}{l}0.04 \pm \\
0.01^{\mathrm{a}}\end{array}$ & $\begin{array}{l}0.55 \pm \\
0.05^{\mathrm{c}}\end{array}$ & $\begin{array}{l}0.07 \pm \\
0.01^{\mathrm{a}}\end{array}$ & $\begin{array}{l}0.74 \pm \\
0.04^{\mathrm{d}}\end{array}$ & $\begin{array}{l}0.09 \pm \\
0.01^{\mathrm{a}}\end{array}$ \\
\hline 4-Hydroxybenzoic acid & 8.04 & N.D. & $\begin{array}{l}0.05 \pm \\
0.01^{\mathrm{b}}\end{array}$ & $\begin{array}{l}0.18 \pm \\
0.01^{\mathrm{a}}\end{array}$ & $\begin{array}{l}0.17 \pm \\
0.01^{\mathrm{a}}\end{array}$ & $\begin{array}{l}0.48 \pm \\
0.02^{\mathrm{d}}\end{array}$ & $\begin{array}{l}0.42 \pm \\
0.01^{c}\end{array}$ & $0.90 \pm 0.01^{\mathrm{f}}$ & $\begin{array}{l}0.62 \pm \\
0.01^{\mathrm{e}}\end{array}$ \\
\hline p-Hydroxybenzaldehyde & 10.32 & N.D. & $\begin{array}{l}0.15 \pm \\
0.01^{\mathrm{a}}\end{array}$ & $\begin{array}{l}0.21 \pm \\
0.02^{\mathrm{a}}\end{array}$ & $\begin{array}{l}0.48 \pm \\
0.04^{\mathrm{b}}\end{array}$ & $\begin{array}{l}0.50 \pm \\
0.01^{\mathrm{b}}\end{array}$ & $\begin{array}{l}1.11 \pm \\
0.14^{\mathrm{d}}\end{array}$ & $\begin{array}{l}0.91 \pm \\
0.02^{\mathrm{c}}\end{array}$ & $1.5 \pm 0.2^{\mathrm{e}}$ \\
\hline \multicolumn{10}{|l|}{ FLAVONOIDS } \\
\hline Quercetin-3-rhamnopiranoside & 13.90 & N.D. & N.D. & $\begin{array}{l}0.02 \pm \\
0.01^{\mathrm{a}}\end{array}$ & N.D. & $\begin{array}{l}0.09 \pm \\
0.01^{\mathrm{b}}\end{array}$ & N.D. & $\begin{array}{l}0.14 \pm \\
0.01^{\mathrm{c}}\end{array}$ & N.D. \\
\hline Luteolin & 17.70 & N.D. & N.D. & $\begin{array}{l}0.30 \pm \\
0.04^{\mathrm{c}}\end{array}$ & $\begin{array}{l}0.23 \pm \\
0.01^{\mathrm{b}}\end{array}$ & N.D. & $\begin{array}{l}0.05 \pm \\
0.01^{\mathrm{a}}\end{array}$ & N.D. & $\begin{array}{l}0.05 \pm \\
0.01^{\mathrm{a}}\end{array}$ \\
\hline Quercetin & 17.90 & N.D. & N.D. & $\begin{array}{l}0.55 \pm \\
0.03^{\mathrm{c}}\end{array}$ & $\begin{array}{l}0.04 \pm \\
0.01^{\mathrm{a}}\end{array}$ & $\begin{array}{l}0.40 \pm \\
0.01^{\mathrm{b}}\end{array}$ & $\begin{array}{l}0.03 \pm \\
0.01^{\mathrm{a}}\end{array}$ & $\begin{array}{l}0.40 \pm \\
0.01^{b}\end{array}$ & $\begin{array}{l}0.03 \pm \\
0.01^{\mathrm{a}}\end{array}$ \\
\hline Kaempferol & 20.60 & N.D. & N.D. & $\begin{array}{l}0.03 \pm \\
0.01\end{array}$ & N.D. & Traces & N.D. & Traces & N.D. \\
\hline Isorhamnetin & 21.20 & N.D. & N.D. & $\begin{array}{l}0.02 \pm \\
0.01\end{array}$ & Traces & N.D. & Traces & N.D. & N.D. \\
\hline \multicolumn{10}{|l|}{ CAPSAICINOIDS AND RELATED COMPOUNDS } \\
\hline Nonivamide & 25.40 & N.D. & N.D. & $\begin{array}{l}0.95 \pm \\
0.08^{\mathrm{b}}\end{array}$ & N.D. & $\begin{array}{l}0.43 \pm \\
0.01^{\mathrm{a}}\end{array}$ & N.D. & $\begin{array}{l}0.53 \pm \\
0.03^{\mathrm{ab}}\end{array}$ & $2.7 \pm 0.3^{\mathrm{c}}$ \\
\hline Capsaicin & 26.00 & N.D. & N.D. & $\begin{array}{l}0.94 \pm \\
0.01^{\mathrm{a}}\end{array}$ & $1.4 \pm 0.7^{\mathrm{a}}$ & $\begin{array}{l}0.81 \pm \\
0.09^{\mathrm{a}}\end{array}$ & $1.2 \pm 0.5^{\mathrm{a}}$ & $\begin{array}{l}0.78 \pm \\
0.01^{\mathrm{a}}\end{array}$ & $1.3 \pm 0.4^{\mathrm{a}}$ \\
\hline TOTAL ( $\mu$ moles) & & $\begin{array}{l}12.3 \pm \\
0.2^{\mathrm{a}}\end{array}$ & $17 \pm 3^{\mathrm{a}}$ & $\begin{array}{l}60.8 \pm \\
6.7^{\mathrm{c}}\end{array}$ & $\begin{array}{l}73.4 \pm \\
2.1^{\mathrm{d}}\end{array}$ & $133 \pm 6^{b}$ & $101 \pm 1^{\mathrm{e}}$ & $191 \pm 3^{f}$ & $134 \pm 1^{b}$ \\
\hline
\end{tabular}

${ }^{1}$ Values represent mean $\pm S D(n=3)$. Different lowercase letters in the same row indicate significant difference (p $\left.<0.05\right)$. N.D. $=$ not detected.

hydroxyphenylacetic acid was detected with a significantly increasing tendency; from 33 and $32 \mu$ moles at $24 \mathrm{~h}$ to 94 and $63 \mu$ moles at $72 \mathrm{~h}$ for RGS and CGS, respectively.

Regarding flavonoids, glycosylated derivatives of both flavonols and flavones were absent in the fermentation samples, only detecting low amounts of quercetin-3-rhamnopiranoside in RGS, with a discrete timedependent relation. The aglycon forms detected (luteolin, quercetin, kaempferol and isorhamnetin) were also present in low amounts and no time-dependent relationship was observed. Colonic fermentation of quercetin is related to the formation of 3,4-dihydroxyphenylpropionic acid, via C-ring fission, accounting for the increase in the concentration of 3,4-dihydroxyphenylpropionic acid. However, the amount of 3,4dihydroxyphenylpropionic acid quantified in the fermentation samples was low taking into account the amount of quercetin present in the digested samples (from 40 to 63 and $32-31 \mathrm{mg} / 100 \mathrm{~g} \mathrm{dw}$ of quercetin and its glycosidic derivatives for RGS and CGS, respectively). Dehydroxylation of 3,4-dihydroxyphenylacetic to form particularly 3-hydroxyphenylpropionic acid contributed to this.

Benzoic acid detected in the fermented samples may preferentially come from decarboxylation of phenylacetic acid, and in a lower rate from hydrolysis of glycosylated benzoic acids present in the digested sauces (Table 3 ).

Regarding capsaicinoids, nonivamide could be generated by demethylation and hydrogenation of the carbon side chain of capsaicin (Fig. 3), taking into account the increased amount of nonivamide (up to $3 \mu \mathrm{mol}$ at $72 \mathrm{~h}$ ) observed during CGS fermentation, whereas there was a more or less stable amount of capsaicin. The evolution of this compound in the fermented RGS was more heterogeneous. The metabolite nonivamide was previously reported by Ovando-Martínez, Gámez-Meza, Molina-Domínguez, Hayano-Kanashiro, and Medina-Juárez (2018) during the in vitro colonic fermentation of Chiltepin hot pepper. It is also worth mentioning that a recent study with capsaicin showed some correlations between gut microbiota composition and health effects. This study described that healthy volunteers who followed a diet containing capsaicin belonged to the so-called Bacteroides enterotype, who showed stronger effects on metabolic and inflammatory markers than the so-called Prevotella enterotype (Kang et al., 2016).

Concerning 3-(3,4-dihydrophenyl)propionic acid, another colonic metabolite formed from the fermentation of green Mexican sauces, Larrosa et al. (2009) associated its content in fecal water with lower 


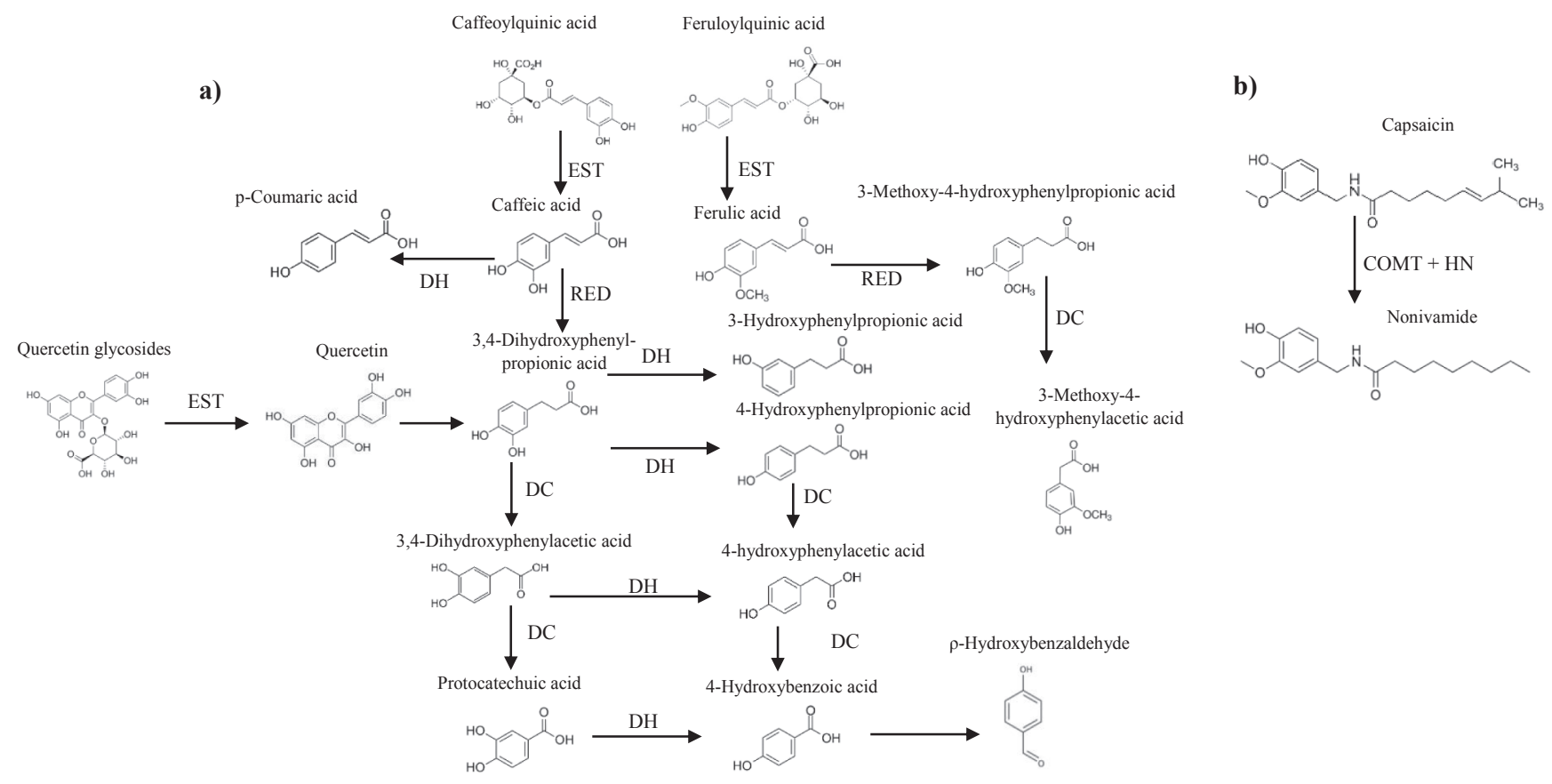

Fig. 3. Biotransformation pathways of the main phenolic compounds (PC) contained in predigested raw green sauce (RGS) and cooked green sauce (CGS). a) Hydroxycinnamate and flavonoid pathway. b) Capsaicinoid pathway. 3-(3,4)HPA: 3-(3,4-dihydroxyphenyl)propionic acid; 3,4-DAA: 3-4-dihydroxyphenylacetic acid; 3-(3)HPA: 3-(3-hydroxyphenyl)propionic acid; 3-(p)HPA: 3-(p-hydroxyphenyl)propionic acid; DC: decarboxylases; DH: dehydrogenases; EST: esterases; RED: reductases. Based on data of Espín et al. (2017), Williamson and Clifford (2017) and Williamson et al. (2018).

weight loss in dextran sodium sulfate-induced colitis rat model. In contrast, 4-hydroxyphenylacetic acid, the most abundant colonic metabolite formed from the fermentation of both RGS and CGS, has been related to depression and anxiety (Zabela et al., 2016).

The amount of colonic metabolites formed after fermentation of predigested RGS and CGS increased over time. A direct relationship between concentration and fermentation time was obtained, although the final amount of metabolites produced was significantly higher ( $<<$ 0.05) in RGS fermentation samples (191 $\pm 3 \mu \mathrm{M}$, respectively) than CGS fermentation samples (134 $\pm 1 \mu \mathrm{M}$, respectively) in spite of the significantly higher PC amount present in the digested CGS than in digested RGS. In this context, cooking process increased the amount of both PC and insoluble indigestible fraction (IIF) in CGS. IIF is comprised mainly of insoluble dietary fiber, with components such as cellulose that may interact with PC thereby decreasing PC bioavailability (Jakobek \& Matić, 2019). Therefore, the higher amount of IIF in cooked sauce compared to its homologue raw sauce presumably interfered in the total amount of the colonic metabolites formed from CGS compared to RGS.

\section{Conclusions}

Cooking of husk tomato (Physalis ixocarpa Brot. ex. Horm) affected the content of IF and PC in green Mexican sauces, so that they were slightly higher in CGS than in RGS. The mixture of ingredients used to prepare the studied sauces resulted in to a wide and heterogeneous profile of phenolic compounds belonging to different groups. Among these, flavonoids were the most abundant in the original sauces $(80.6$ and $81.6 \%$ for RGS and CGS, respectively) followed by hydroxycinnamic acids (15.5 and $12.8 \%$ ) and hydroxybenzoic acids (0.5 and $1.2 \%$ ), respectively. Capsaicin, a capsaicinoid identified in both RGS and CGS at low amounts ( 3.5 and $4.5 \%$ ), is only present in hot pepper and presents interesting biological potential. Digestion of both sauces significantly diminished its PC content, although flavonoids continued being the most abundant group of polyphenols (88.2 and $92 \%$ in RGS and CGS, respectively). These results also indicated that significant amounts of PC could be absorbed in the small intestine, although the dialysis process does not properly mimic the transport processes (active or passive) in the small intestine.

Regarding the biotransformation of PC in predigested RGS and CGS, the major metabolites generated were 3-( $\rho$-hydroxyphenyl) propionic acid, 3-(3-hydroxyphenyl) propionic acid and 4-hydroxyphenylacetic acid. These results are the first obtained on the in vitro colonic fermentation of Mexican sauces and should be considered in future studies that evaluate the health effects related to the consumption of this staple food in the Mexican diet.

\section{CRediT authorship contribution statement}

Alicia Paulina Cárdenas-Castro: Formal analysis, Investigation, Writing - original draft. Koen Venema: Methodology, Software, Validation, Resources, Writing - review \& editing, Project administration. Beatriz Sarriá: Writing - review \& editing. Laura Bravo: Resources, Writing - review \& editing. Sonia G. Sáyago-Ayerdi: Conceptualization, Methodology, Project administration, Resources, Writing - review \& editing. Raquel Mateos: Methodology, Validation, Resources, Writing - review \& editing, Visualization, Project administration.

\section{Declaration of Competing Interest}

The authors declare that they have no known competing financial interests or personal relationships that could have appeared to influence the work reported in this paper.

\section{Acknowledgements}

We are grateful to the Analysis Service Unit (USTA) facilities of ICTAN for the analysis of Chromatography and Mass Spectrometry. RMB and SGSA acknowledge to Red Iberoamericana de Alimentos Autóctonos Subutilizados (ALSUB-CYTED, 118RT0543). The Spanish Ministry of Science, Innovation and Universities (Project AGL2015-69986-R) is also acknowledged. Alicia Paulina Cárdenas Castro thanks CONACYTMexico for the financial support, grant registration number: 662703 
and Koen Venema acknowledges the support of the Dutch Province of Limburg.

\section{Appendix A. Supplementary material}

Supplementary data to this article can be found online at https://doi. org/10.1016/j.foodres.2020.109917.

\section{References}

Alvarez-Parrilla, E., de la Rosa, L. A., Amarowicz, R., \& Shahidi, F. (2011). Antioxidant activity of fresh and processed Jalapeno and Serrano peppers. Journal of Agricultural and Food Chemistry, 59(1), 163-173. https://doi.org/10.1021/jf103434u.

Barros, L., Dueñas, M., Dias, M. I., Sousa, M. J., Santos-Buelga, C., \& Ferreira, I. C. (2012). Phenolic profiles of in vivo and in vitro grown Coriandrum sativum L. Food Chemistry, 132(2), 841-848. https://doi.org/10.1016/j.foodchem.2011.11.048.

Bohn, T. (2014). Dietary factor affecting polyphenol bioavailability. Nutrition Reviews, 72 (7), 429-452. https://doi.org/10.1111/nure.12114.

Bravo, L., Goya, L., \& Lecumberri, E. (2007). LC/MS characterization of phenolic constituents of mate (Ilex paraguariensis, St. Hil.) and its antioxidant activity compared to commonly consumed beverages. Food Research International, 40(3), 393-405. https://doi.org/10.1016/j.foodres.2006.10.016.

Cárdenas-Castro, A. P., Perales-Vázquez, G.d. C., de la Rosa, L. A., Zamora-Gasga, RuizValdiviezo, V. M., Alvarez-Parrilla, E., \& Sáyago-Ayerdi, S. G. (2019). Sauces: An undiscovered healthy complement in Mexican cuisine. International Journal of Gastronomy and Food Science, 17, Article 100154. https://doi.org/10.1016/j. ijgfs.2019.100154.

Cárdenas-Castro, A. P., Pérez-Jiménez, J., Bello-Pérez, L. A., Tovar, J., \& SáyagoAyerdi, S. G. (2020). Bioaccessibility of phenolic compounds in common beans (Phaseolus vulgaris L.) after in vitro gastrointestinal digestion: A comparison of two cooking procedures. Cereal Chemistry.. https://doi.org/10.1002/cche.10283.

Catalkaya, G., Venema, K., Lucini, L., Rocchetti, G., Delmas, D., Daglia, M., ... Xiao, J. (2020). Interaction of dietary polyphenols and gut microbiota: Microbial metabolism of polyphenols, influence on the gut microbiota, and implications on host health. Food Frontiers, 1(2), 109-133. https://doi.org/10.1002/fft2.25.

Chigwedere, C. M., Nkonkola, C. M., Rai, S., Kyomugasho, C., Kermani, Z. J., Pallares, A. P., ... Hendrickx, M. E. (2019). Cotyledon pectin molecular interconversions explain pectin solubilization during cooking of common beans (Phaseolus vulgaris). Food Research International, 116, 462-470. https://doi.org/ 10.1016/j.foodres.2018.08.062.

Espín, J. C., González-Sarrías, A., \& Tomás-Barberán, F. A. (2017). The gut microbiota: A key factor in the therapeutic effects of (poly)phenols. Biochemical Pharmacology, 139, 82-93. https://doi.org/10.1016/j.bcp.2017.04.033.

ENSANUT (2016). Encuesta Nacional de Salud y Nutrición. http://promocion.salud.gob. mx/dgps/descargas1/doctos_2016/ensanut_mc_2016-310oct.pdf Accessed 12 October 2020.

Gómez-Juaristi, M., Martínez-López, S., Sarria, B., Bravo, L., \& Mateos, R. (2018). Bioavailability of hydroxycinnamates in an instant green/roasted coffee blend in humans. Identification of novel colonic metabolites. Food \& Function, 9(1), 331-343. https://doi.org/10.1039/c7fo01553d.

Gómez-Romero, M., Segura-Carretero, A., \& Fernández-Gutiérrez, A. (2010). Metabolite profiling and quantification of phenolic compounds in methanol extracts of tomato fruit. Phytochemistry, 71(16), 1848-1864. https://doi.org/10.1016/j. phytochem.2010.08.002.

Gorinstein, S., Leontowicz, H., Leontowicz, M., Namiesnik, J., Najman, K., Drzewiecki, J., .. Trakhtenberg, S. (2008). Comparison of the main bioactive compounds and antioxidant activities in garlic and white and red onions after treatment protocols. Journal of Agricultural and Food Chemistry, 56(12), 4418-4426. https://doi.org/ 10.1021/jf800038h.

Jakobek, L., \& Matić, P. (2019). Non-covalent dietary fiber-polyphenol interactions and their influence on polyphenol bioaccessibility. Trends in Food Science \& Technology, 83, 235-247. https://doi.org/10.1016/j.tifs.2018.11.024.

Juániz, I., Ludwig, I. A., Bresciani, L., Dall'Asta, M., Mena, P., Del Rio, D., ... de Peña, M.P. (2016). Catabolism of raw and cooked green pepper (Capsicum annuum) (poly) phenolic compounds after simulated gastrointestinal digestion and faecal fermentation. Journal of Functional Foods, 27, 201-213. https://doi.org/10.1016/j. jff.2016.09.006.

Kang, C., Zhang, Y., Zhu, X., Liu, K., Wang, X., Chen, M., ... Huang, L. (2016). Healthy subjects differentially respond to dietary capsaicin correlating with specific gut enterotypes. The Journal of Clinical Endocrinology \& Metabolism, 101(12), 4681-4689. https://doi.org/10.1210/jc.2016-2786.

Larrosa, M., Luceri, C., Vivoli, E., Pagliuca, C., Lodovici, M., Moneti, G., \& Dolara, P. (2009). Polyphenol metabolites from colonic microbiota exert anti-inflammatory activity on different inflammation models. Molecular Nutrition \& Food Research, 53 (8), 1044-1054. https://doi.org/10.1002/mnfr.200800446.

Maathuis, A., Hoffman, A., Evans, A., Sanders, L., \& Venema, K. (2009). The effect of the undigested fraction of maize products on the activity and composition of the microbiota determined in a dynamic in vitro model of the human proximal large intestine. Journal of the American College of Nutrition, 28(6), 657-666. https://doi. org/10.1080/07315724.2009.10719798.

Medina-Medrano, J. R., Almaraz-Abarca, N., González-Elizondo, M. S., Uribe-Soto, J. N., González-Valdez, L. S., \& Herrera-Arrieta, Y. (2015). Phenolic constituents and antioxidant properties of five wild species of Physalis (Solanaceae). Botanical Studies, 56(1), 1-13. https://doi.org/10.1186/s40529-015-0101-y.

Mercado-Mercado, G., Blancas-Benítez, F. J., Zamora-Gasga, V. M., \& SáyagoAyerdi, S. G. (2019). Mexican traditional plant-foods: Polyphenols bioavailability, gut microbiota metabolism and impact human health. Current Pharmaceutical Design, 25(32), 3434-3456. https://doi.org/10.2174/1381612825666191011093753.

Miean, K. H., \& Mohamed, S. (2001). Flavonoid (myricetin, quercetin, kaempferol, luteolin, and apigenin) content of edible tropical plants. Journal of Agricultural and Food Chemistry, 49(6), 3106-3112. https://doi.org/10.1021/jf000892m.

Morales-Contreras, B. E., Rosas-Flores, W., Contreras-Esquivel, J. C., Wicker, L., \& Morales-Castro, J. (2018). Pectin from husk tomato (Physalis ixocarpa Brot.): Rheological behavior at different extraction conditions. Carbohydrate Polymers, 179, 282-289. https://doi.org/10.1016/j.carbpol.2017.09.097.

Ornelas-Paz, J., Martínez-Burrola, J. M., Ruiz-Cruz, S., Santana-Rodríguez, V., IbarraJunquera, V., Olivas, G. I., \& Pérez-Martínez, J. (2010). Effect of cooking on the capsaicinoids and phenolics contents of Mexican peppers. Food Chemistry, 119(4), 1619-1625. https://doi.org/10.1016/j.foodchem.2009.09.054.

Ovando-Martínez, M., Gámez-Meza, N., Molina-Domínguez, C. C., Hayano-Kanashiro, C., \& Medina-Juárez, L. A. (2018). Simulated gastrointestinal digestion, bioaccessibility and antioxidant capacity of polyphenols from red Chiltepin (Capsicum annuum L. Var. glabriusculum) grown in northwest Mexico. Plant Foods for Human Nutrition, 73 (2), 116-121. https://doi.org/10.1007/s11130-018-0669-y.

Pasierski, M., \& Szulczyk, B. (2020). Capsaicin inhibits sodium currents and epileptiform activity in prefrontal cortex pyramidal neurons. Neurochemistry International, 104709. https://doi.org/10.1016/j.neuint.2020.104709.

Perales-Vázquez, G.d. C., Mercado-Mercado, G., de la Rosa, A., \& Sáyago-Ayerdi, S. G. (2020). Bioaccesibilidad y cinética de liberación in vitro de compuestos fenólicos en algunas salsas de la cocina mexicana. TIP Revista Especializada en Ciencias QuímicoBiológicas, 23.

Quatrin, A., Rampelotto, C., Pauletto, R., Maurer, L. H., Nichelle, S. M., Klein, B., ... de Menezes, C. R. (2020). Bioaccessibility and catabolism of phenolic compounds from jaboticaba (Myrciaria trunciflora) fruit peel during in vitro gastrointestinal digestion and colonic fermentation. Journal of Functional Foods, 65, Article 103714. https:// doi.org/10.1016/j.jff.2019.103714.

Saura-Calixto, F., García-Alonso, A., Goñi, I., \& Bravo, L. (2000). In vitro determination of the indigestible fraction in foods: An alternative to dietary fiber analysis. Journal of Agricultural and Food Chemistry, 48(8), 3342-3347. https://doi.org/10.1021/ jf0000373.

Sáyago-Ayerdi, S. G., Zamora-Gasga, V. M., \& Venema, K. (2020). Changes in gut microbiota in predigested Hibiscus sabdariffa L. calyces and Agave (Agave tequilana weber) fructans assessed in a dynamic in vitro model (TIM-2) of the human colon. Food Research International, 132, Article 109036. https://doi.org/10.1016/j. foodres.2020.109036.

Serra, A., Macià, A., Romero, M. P., Reguant, J., Ortega, N., \& Motilva, M. J. (2012). Metabolic pathways of the colonic metabolism of flavonoids (flavonols, flavones and flavanones) and phenolic acids. Food Chemistry, 130(2), 383-393. https://doi.org/ 10.1016/j.foodchem.2011.07.055.

Tabernero, M., Venema, K., Maathuis, A. J., \& Saura-Calixto, F. D. (2011). Metabolite production during in vitro colonic fermentation of dietary fiber: Analysis and comparison of two European diets. Journal of Agricultural and Food Chemistry, 59(16), 8968-8975. https://doi.org/10.1021/jf201777w.

Venema, K., Nuenen, M.v., Smeets-Peeters, M., Minekus, M., \& Havenaar, R. (2000). TNO's in vitro large intestinal model: An excellent screening tool for functional food and pharmaceutical research. Ernährung, 24(12), 558-564.

Venema, K., \& Van den Abbeele, P. (2013). Experimental models of the gut microbiome. Best Practice \& Research Clinical Gastroenterology, 27(1), 115-126. https://doi.org/ 10.1016/j.bpg.2013.03.002.

Wikan, N., Tocharus, J., Sivasinprasasn, S., Kongkaew, A., Chaichompoo, W., Suksamrarn, A., \& Tocharus, C. (2020). Capsaicinoid nonivamide improves nonalcoholic fatty liver disease in rats fed a high-fat diet. Journal of Pharmacological Sciences, 143, 188-198.

Williamson, G., \& Clifford, M. N. (2017). Role of the small intestine, colon and microbiota in determining the metabolic fate of polyphenols. Biochemical Pharmacology, 139, 24-39. https://doi.org/10.1016/j.bcp.2017.03.012.

Williamson, G., Kay, C. D., \& Crozier, A. (2018). The bioavailability, transport, and bioactivity of dietary flavonoids: A review from a historical perspective. Comprehensive Reviews in Food Science and Food Safety, 17(5), 1054-1112. https:// doi.org/10.1111/1541-4337.12351.

Zabela, V., Sampath, C., Oufir, M., Moradi-Afrapoli, F., Butterweck, V., \& Hamburger, M. (2016). Pharmacokinetics of dietary kaempferol and its metabolite 4-hydroxyphenylacetic acid in rats. Fitoterapia, 115, 189-197. https://doi.org/10.1016/j. fitote.2016.10.008.

Zhang, C.-R., Khan, W., Bakht, J., \& Nair, M. G. (2016). New antiinflammatory sucrose esters in the natural sticky coating of tomatillo (Physalis philadelphica), an important culinary fruit. Food Chemistry, 196, 726-732. https://doi.org/10.1016/j. foodchem.2015.10.007. 